\title{
Spatial distribution of microphytobenthos, meiofauna and macrofauna in the north-western Adriatic Sea: a synoptic study
}

\author{
Annalisa Franzo," Tamara Cibic, Paola Del Negro, Cinzia De Vittor \\ Sezione Oceanografia, Istituto Nazionale di Oceanografia e Geofisica Sperimentale (OGS), via A. Piccard 54, I-34151 Trieste, Italy
}

\begin{abstract}
In view of the general paucity of integrated information on offshore benthic communities in the Adriatic Sea and given the vulnerability of this particular coastal system, microphytobenthos, meiofauna and macrofauna were synoptically investigated in front of the Emilia-Romagna coast (northern Adriatic Sea) in September 2010 and March 2011. As required by the Marine Strategy Framework Directive, which extends its action beyond the territorial waters (within $12 \mathrm{nmi}$ ) of the Member States, our findings could help to fill the gap of knowledge on the environmental status in offshore areas since the study was carried out also at $>12 \mathrm{nmi}$ from the coastline. In fact, sediment samples for the analysis of the benthic communities were collected from a 10-point-station grid that covered an area of about $400 \mathrm{~km}^{2}$ with water depths ranging from 13 to $50 \mathrm{~m}$. The variability of the sediment grain size and other chemical variables in the sediment suggests the presence of two distinct environmental contexts that enhance the proliferation of different benthic communities. At the inshore stations (depth $<20 \mathrm{~m}$ ) the higher sand percentages and the maxima of dissolved inorganic nitrogen concentrations indicated the presence of hydrodynamic perturbations and the influence of nutrient loads of terrestrial origin. Inshore, both meio- and macrofaunal communities were poorly structured and dominated by relatively more opportunistic taxa, such as nematodes and the bivalve Corbula gibba. Offshore stations (depth $>20 \mathrm{~m}$ ) had muddier sediments, which likely exerted a greater retention of sediment-bound organic matter. These conditions seemed to favour benthic deposit feeders like meio- and macrofaunal annelids. Surprisingly, a conspicuous microphytobenthic community, mainly represented by the diatom Paralia sulcata, has been observed even at remarkable depths $(\sim 50$ $\mathrm{m}$ ) opening new questions regarding the role of these organisms in dim-light conditions. Although the investigated benthic communities were, to some extent, moderately influenced by multiple stressors, the co-existence of sensitive taxa (such as meiofaunal copepods and the amphipod Ampelisca spp.) with opportunistic ones (i.e., C. gibba) suggests that the benthic domain in the investigated area is not severely impacted.
\end{abstract}

Key words: Microphytobenthos; meiofauna; macrofauna; Adriatic Sea; offshore benthos.

Received: July 2015. Accepted: December 2015.

\section{INTRODUCTION}

Coastal zones are intensively populated by humans worldwide. Today, approximately half of the world's population lives within 200 kilometres from the oceans' coastline, and this trend is likely to continue in next decades (Creel, 2003). As a consequence, most anthropogenic activities are concentrated along the coast, resulting in multiple impacts on both terrestrial and marine environments. In the Adriatic Sea, the densely populated coast of the Emilia Romagna region hosts a plethora of human activities including, among others, fishing, tourism, shellfish farming, maritime transport and gas extraction. This area is also influenced by the Po River, the most important freshwater input of the Adriatic Sea, and other secondary watercourses that contribute to significant inputs of nutrients, of both natural and human origin, to the sea. Thus, the benthic domain along the Emilia-Romagna coast is subjected to a wide spectrum of stressors all likely affecting benthic communities. During the 80ies, the increased nutrient inputs from the Po River caused acute alteration events ascribable to eutrophication, including red tides, anoxic bottom conditions and mass mortalities of benthic animals (Crema et al., 1991 and references therein). Nevertheless, in the last decade, the frequency of such events decreased likely due to the reduction of river nutrient loads (especially phosphates) and due to a sensible decrease in river runoff. Consequently, in the northern Adriatic Sea, the general pattern seems to have switched from the eutrophic situation of the 80ies towards oligotrophication (Mozetič et al., 2010).

In the benthic domain, microphytobenthos (MPB), meiofauna and macrofauna are closely linked one to other through numerous interactions, which contribute to the complexity of the benthic food web (Albertelli et al., 1999). MPB constitute the only autochthonous source of primary production on non-vegetated sediments of shallow marine areas (Larson and Sundbäck, 2008 and references therein). Consequently, as principal oxygen producers, they allow the aerobic degradation of both autochthonous and settled organic matter (Cibic et al., 2007 and references therein). Moreover, MPB play a key role 
in the carbon cycle in littoral environments as producers of new organic matter that can enter either the benthic or the pelagic trophic webs (Barranguet, 1997). MPB can also regulate nutrient fluxes by acting as a sort of nutrient filter: photosynthetically active microalgae, in fact, by the uptake of inorganic nutrients from the sediment pore water, can reduce nutrient fluxes towards the overlying water (Sundbäck et al., 2004). Meiofauna, including different trophic groups (i.e., deposit feeders, microalgae feeders, bacterivores and predators; Balsamo et al., 2010) and being able to influence nutrient regeneration (Bonaglia et al., 2014), represent a fundamental link between organic detritus and higher trophic levels, therefore playing a paramount ecological role within the surface sediments (Balsamo et al., 2010 and references therein). In addition, some taxa, preying upon juvenile macrofauna, which are temporarily part of meiofauna, exert a bottleneck mechanism, controlling both the structure and the composition of the macrofaunal community (Danovaro et al., 1995). In turn, meiofaunal organisms are intensively exposed to predation pressure by several small macrobenthic animals such as small shrimps, crabs, polychaetes, ophiuroids, and juvenile fishes (Balsamo et al., 2010 and references therein). Sediment bioturbation due to both meio- and macrofauna enhances oxygen diffusion rates favouring aerobic degradation of organic matter by prokaryotes (Zonneveld et al., 2010).

Overall, all size classes of benthic communities can be suitable for investigating and characterising the habitat where they live. They are simultaneously exposed to several environmental stressors that may modify each of them in either direct or indirect ways. Directly, by altering their abundances and species composition and, indirectly, by inducing further changes at other trophic levels, e.g. modifying predator-prey relationships or altering primary production and respiration (Semprucci et al., 2015). Although microphytobenthos, meiofauna and macrofauna have different (but partially overlapping) roles in the functioning of sedimentary habitats and show different response times to anthropogenic pressures, they altogether represent an ideal tool for assessing the state of the benthic environment (Semprucci et al., 2013 and references therein).

Along the Emilia-Romagna coastline, some synoptic studies have been already conducted integrating the analyses of meio- and macrofauna with prokaryotes (Semprucci et al., 2010) or Foraminifera (Frontalini et al., 2011; Semprucci et al., 2013). On the other hand, to the best of our knowledge, MPB have been only rarely taken into consideration in the Adriatic Sea (Totti, 2003; Cibic and Facca, 2010). The unique available study refers to strictly shallow communities (depth $<15 \mathrm{~m}$ ), so that, to date, there is a serious lack of knowledge on the offshore and deeper ones. There is an urgency to fill such gap in order to face the requirements of one of the main European umbrella regulations for waters systems, i.e. the Marine Strategy Framework Directive (MSFD, 2008/56/EC, European Commission, 2008). The MSFD, in fact, extends its action to offshore marine environments, located beyond the territorial waters of the Member States, i.e. at more than 12 nmi from the coastline, since even such areas could be affected by anthropogenic stressors.

To provide new insights about offshore benthic communities in the Adriatic Sea, we conducted a study in front of the Emilia-Romagna coast (northern Adriatic Sea) in a wide area that partially protrudes beyond the Italian territorial waters. Structure and taxonomic composition of MPB (with a focus on diatoms), meiofauna and macrofauna were investigated synoptically and related to the characteristics of the sedimentary environment. More precisely, the aim of the present study was to answer the following questions: 1) What are the spatial distribution patterns of MPB, meiofauna and macrofauna along a water depth gradient? 2) Is there an indication of possible disturbance factors affecting the benthic domain?

\section{METHODS}

\section{Study area}

The northern Adriatic Sea is a shallow sub-basin of the Adriatic characterised by a morphologically complex coastline, which leads to variable hydrodynamic and sedimentary environments. The hydrology is influenced by several forcing factors like winds and river runoffs, and the general circulation is cyclonic. Freshwater (mean flow rate of $1496 \mathrm{~m}^{3} \mathrm{~s}^{-1}$ in the period 1917-2008, Cozzi and Giani, 2011) is discharged into the basin from major rivers along the northern and north-western coasts. Among them, the Po River represents the major input of nutrientrich waters, accounting for about one third of the total riverine freshwater input in the Adriatic. Its plume, characterised by relatively fresh and mesotrophic waters, can spread over the entire northern sub-basin as a thin surface layer in summer while it is reduced and flows directly southward along the Italian coast in winter (Poulain et al., 2001 and references therein).

The sedimentation pattern matches the hydrodynamic circulation (Tomadin, 2000; Ravaioli et al., 2003). It consists of a narrow strip of recent sands along the coast followed by a broad belt of muddy sediments. Going offshore, there is a transitional muddy zone characterised by a gradual increase of sand fraction, which becomes dominant in a wide open sandy shelf area with little or no recent sedimentation (known as relict sands) (Colantoni et al., 1985). Although the northern Adriatic shelf is a relatively low-energy environment with small tidal ranges and wave heights, after flood events, ephemeral deposits of sediments are generated and subsequently remobilized 
by waves to form dense flows (Traykovski et al., 2007). The sediments travel southwards in a series of wind-induced resuspension events promoted by the Bora and Scirocco winds (Fain et al., 2007). The main sources of biogenic elements are autochthonous (plankton) or allochthonous (atmospheric inputs and organic matter derived from soil and transported by rivers). The investigated area is located in front of the Emilia-Romagna coast, an area impacted by several anthropogenic activities, such as the presence of offshore gas platforms (Manoukian et al., 2010), sand extraction for beach replenishment (Simonini et al., 2007) and the dumping of harbour-dredged materials (Simonini et al., 2005b).

\section{Sampling}

The study was carried out in a coastal area between Rimini and Pesaro cities. To characterise both the spatial and temporal variability of chemical, biological and physical parameters in the sediment, a 10-point-station grid, covering an area of about $400 \mathrm{~km}^{2}$, was sampled in Sep- tember 2010 and March 2011 (Fig. 1). St. C01 was located $5.5 \mathrm{~km}$ (2.7 nmi) from the coast, while St. B02, C02 and D02 were, on average, $14.4 \mathrm{~km}(7.4 \mathrm{nmi})$ offshore. St. B03, C03, D03 were $20.8 \mathrm{~km}$ (10.7 nmi) from the coast and St. B04, C04, D04 were located, on average, $27.0 \mathrm{~km}$ (13.8 nmi) offshore. The depth ranged from $\sim 14 \mathrm{~m}$ to $\sim 50$ $\mathrm{m}$ at St. C01 and St. D04, respectively (Tab. 1). In the present study, the depth of $20 \mathrm{~m}$ was considered as the threshold between coastal and offshore stations. Therefore, St. C01, B02, C02 and D02 are referred as inshore stations throughout the paper whereas St. B03, C03, D03, B04, C04 and D04 as offshore stations. In the present study, September and March were chosen as sampling periods because representative of summer and winter conditions for the considered benthic communities in the northern Adriatic Sea (Cibic et al., 2012; N'Siala et al., 2008 and references therein).

For logistical reasons, sediment samples for chemical and biological data were collected within a 15-day period during the September survey and within a 20-day period in March. For grain size, chemical variables and pigments,

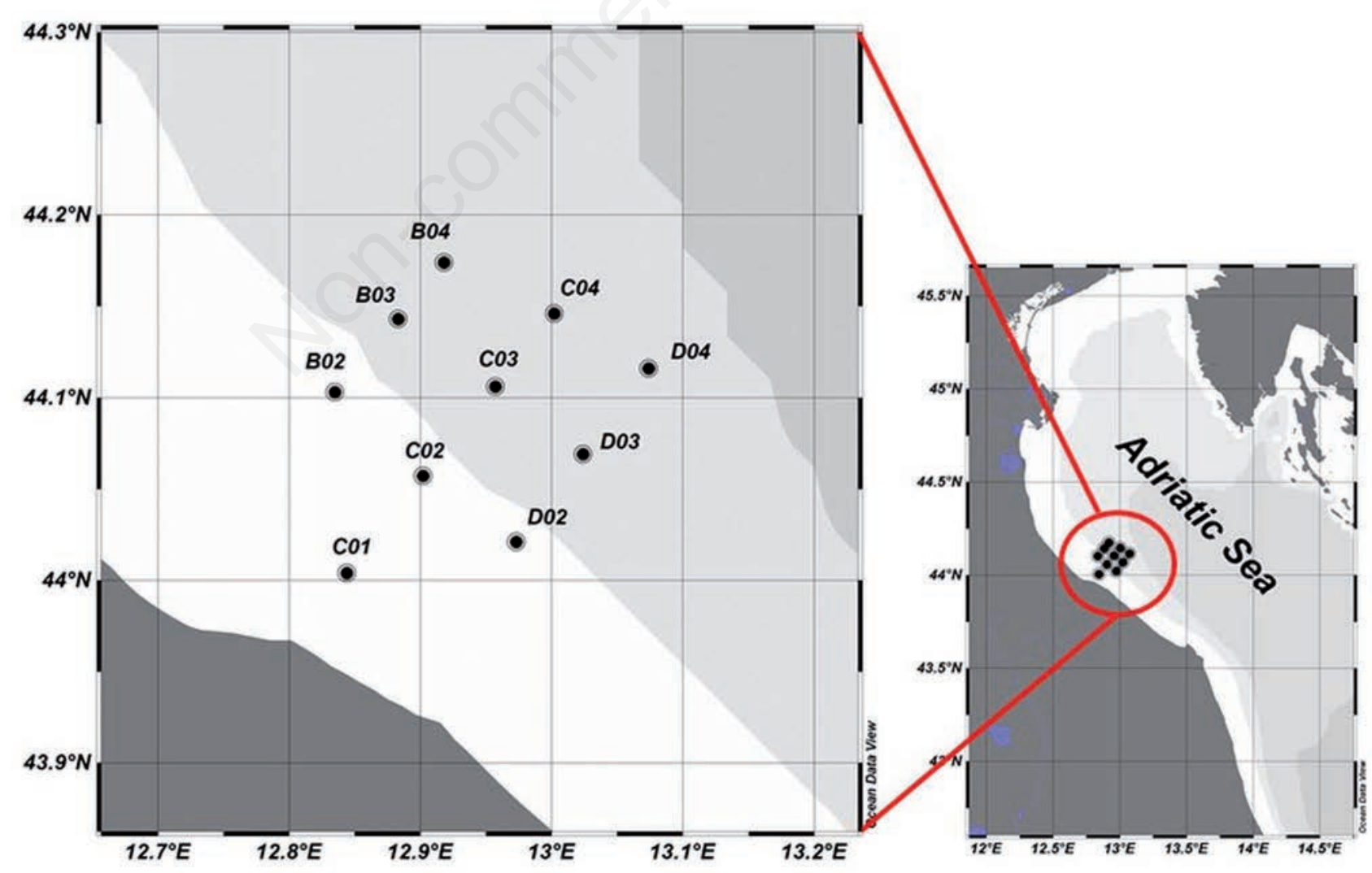

Fig. 1. Location of the study area and structure of the 10-point-station grid. Image drawn by means of ODV software (Schlitzer, 2015). 
virtually undisturbed sediment cores were collected by a KC Haps bottom corer (KC-Denmark, Silkeborg, Denmark) using Plexiglas sample tubes $(16 \mathrm{~cm}$ i.d; $30 \mathrm{~cm}$ length). Sediment cores were partially extruded in a $\mathrm{N}_{2}-$ filled chamber and the oxic layer $(0-1 \mathrm{~cm})$ was collected and homogenised. For dissolved nutrients analysis, pore waters were extracted from surface sediments by centrifugation (3500 rpm, 40 min Hereaous Omnifuge $2000 \mathrm{RS}$ ) at in situ temperature, subsequently recovered under a $\mathrm{N}_{2}$ atmosphere and filtered through $0.45 \mu \mathrm{m}$ pore cellulose acetate filters. For logistical difficulties, the chemical data from St. C02 are not available in March. For MPB and meiofauna, sediment was collected using a Box Corer (25 $\mathrm{cm}$ height; 17x10 cm of sampling area). Sediment cores were subsampled for meiofauna using cut-off plastic syringes $(2.7 \mathrm{~cm}$ i.d., length $11.4 \mathrm{~cm})$ in three replicates at each station, and the remaining oxic layer was collected for microphytobenthic analyses. Macrofauna were sampled in three replicates per station using a Van Veen grab with a $0.1 \mathrm{~m}^{2}$ sampling area. Depth profiles of physical characteristics of the water column were recorded by a Seabird 19 PlusSeacat probe.

\section{Sediment grain size, chemical parameters and pigments}

For grain size analysis, aliquots of sediment (10-15 g) were collected at all stations. Small pebbles and shell fragments were separated from sand and mud fractions by sieving at $2 \mathrm{~mm}$. Each sample was disaggregated and the organic matter oxidized using $10 \%$ hydrogen peroxide (Carlo Erba, Rodano, Italy) at $60^{\circ} \mathrm{C}$ for $24 \mathrm{~h}$. The analyses were performed using a Malvern Mastersizer 2000 equipped with Hydro 2000s (Malvern Instruments Ltd., Malvern, UK). Data are expressed as percentages of sand, silt and clay.

For total organic carbon (TOC) and total nitrogen (TN) analyses, sediment was freeze-dried and grounded using a mortar, then a pestle and the fraction $>250 \mu \mathrm{m}$ was separated from the rest of the sample. Triplicate subsamples of about 8-12 mg were weighed directly in a capsule $(5 \times 9 \mathrm{~mm})$ on a microultrabalance Perkin Elmer mod. AD4 (accuracy of $0.1 \mu \mathrm{g}$ ). For TOC and TN analyses, silver capsules and tin capsules were used, respectively. Before the TOC determination, subsamples were treated with increasing concentrations of $\mathrm{HCl}(0.1 \mathrm{~N}$ and $1 \mathrm{~N})$ to remove carbonates (Nieuwenhuize et al., 1994). Carbon and nitrogen content were determined using a CHNO-S elemental analyser mod. ECS 4010 (Costech International Spa, Pioltello, Italy) according to Pella and Colombo (1973) and Sharp (1974). Capsule blanks were also analysed. The precision of the analysis was about $3 \%$. The $\mathrm{C}$ and $\mathrm{N}$ contents in the samples are expressed as $\mathrm{mg} \mathrm{C}$ gdry mass ${ }^{-1}$ and mg N gdry mass ${ }^{-1}$.

Dissolved inorganic nutrient concentrations (nitrite,

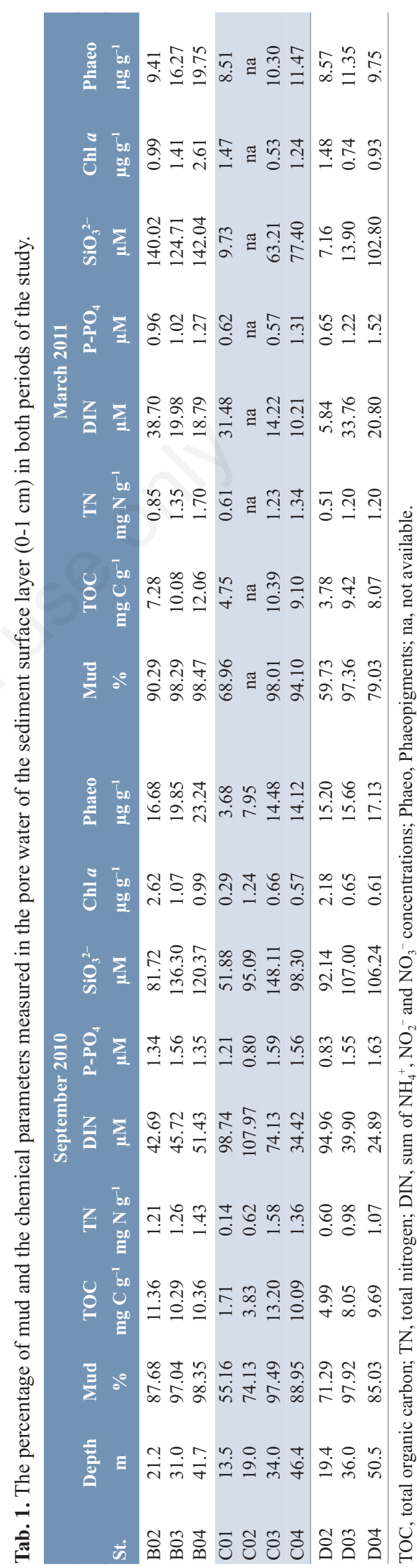


$\mathrm{NO}_{2}^{-}$; nitrate, $\mathrm{NO}_{3}^{-}$; ammonium, $\mathrm{NH}_{4}^{+}$; phosphate, $\mathrm{PO}_{4}^{3-}$; silicate, $\mathrm{SiO}_{3}{ }^{2-}$ ) were analysed in the extracted pore water by a flow-injection spectrophotometric method (Grasshoff et al., 1983). Analyses were performed at room temperature on a five-channel Bran+LuebbeAutoanalyzer 3 Continuous Flow Analyzer (Bran+Luebbe, Norderstedt, Germany), using standard procedures. Performance of the system was checked before and after sample analysis by running replicates of internal standards. The precision of the analysis was $3 \%$.

Pigments were extracted overnight $\left(4^{\circ} \mathrm{C}, 90 \%\right.$ acetone) from $0.7-0.9 \mathrm{~g}$ of wet sediment. After centrifugation (2500 rpm, $20 \mathrm{~min}$ ), the extract was analysed spectrofluorometrically following the procedures described by Lorenzen and Jeffrey (1980). The measurements were performed before (chlorophyll $a, \mathrm{Chl} a, \mu \mathrm{g} \mathrm{g}^{-1}$ ) and after (phaeopigments, Phaeo, $\mu \mathrm{g} \mathrm{g}^{-1}$ ) acidification with 2 drops of $1 \mathrm{~N} \mathrm{HCl}$, using a JASCO FP 6500 spectrofluorometer (450 nm excitement and $665 \mathrm{~nm}$ emission wavelengths). Calibration was made with pure Sigma Chl $a$ standards.

\section{Microphytobenthos}

For MPB, aliquots of $2 \mathrm{~cm}^{3}$ of surface sediment were withdrawn using a syringe and directly fixed with $10 \mathrm{~mL}$ of formaldehyde ( $4 \%$ concentration) buffered solution $\mathrm{CaMg}\left(\mathrm{CO}_{3}\right)_{2}$ (Carlo Erba), in pre-filtered bottom seawater (0.2 $\mu \mathrm{m}$ filters) (Schleicher \& Schuell, Dassel, Germany). After manual stirring, $20 \mu \mathrm{L}$ aliquots of the sediment suspension were drawn off from the slurries and placed in a counting chamber (Thalassia, Trieste, Italy). Only cells containing pigments and not empty frustules were counted under a Leitz inverted light microscope (Leica Microsystems AG, Wetzlar, Germany) (Utermöhl, 1958) at 320X final magnification. The abundance was expressed as cells $\mathrm{cm}^{-3}$. The microalgal taxonomy was based on Round et al. (1992), Cibic and Facca (2010) and the AlgaeBase website (http://www.algaebase.org/). The qualitative identification of microphytobenthic assemblages was carried out to the genus and, when possible, to the species level using floras of Van Heurck (1899), Hendey (1976), Germain (1981), Dexing et al. (1985), Ricard (1987), Tomas (1997) and Witkowski (2000).

\section{Meiofauna}

For the study of the meiofauna, three replicate cores were taken down to the depth of $10 \mathrm{~cm}$. The sediment was fixed with 4\% neutralized formaldehyde and stained with Rose Bengal 1\%o (VWR Prolabo). Sediment samples were sieved through 1000-38 $\mu \mathrm{m}$ mesh nets. The extraction of meiofaunal organisms from the sediment was performed by three times centrifugation with Ludox AM 30 (SigmaAldrich, St. Louis, MO, USA) (density $1.18 \mathrm{~g} \mathrm{~cm}^{-3}$ ) as described by Danovaro et al. (2004). The meiofauna were counted and identified under a stereomicroscope with a final magnification of 40 or $80 \mathrm{X}$ at the major taxonomic level according to Higgins and Thiel (1988); the abundance of the main groups was expressed as number of individuals per $10 \mathrm{~cm}^{2}$ (Higgins and Thiel, 1988).

\section{Macrofauna}

Sediment was sieved through $1000 \mu \mathrm{m}$ mesh to retain the fraction of macrozoobenthic organisms and immediately frozen at $-20^{\circ} \mathrm{C}$ on board (Castelli et al., 2004). After defrosting, organisms were separated from sediment by tweezers, and firstly assigned to their taxon (i.e., molluscs, annelids, amphipods, etc.) and preserved in a Borax buffered solution of $4 \%$ formaldehyde (Carlo Erba Reagents). All the animals were identified to the lowest possible taxonomical level using a stereomicroscope at 7 40X final magnification and counted. For the identification of organisms, the taxonomical keys listed in Morri et al. (2004) were used. The abundance was expressed as number of individuals per $\mathrm{m}^{2}$.

\section{Statistical analyses}

Diversity indexes d (richness of taxa; Margalef, 1986), H' (Shannon and Weaver, 1949) and $\lambda$ (dominance; Simpson, 1949) were calculated for benthic diatom and macrofaunal communities.

To visualize differences among groups of stations (i.e., inshore $v s$ offshore) cluster analyses based on square-root transformed data and Bray-Curtis similarity matrixes with a complete linkage were performed separately for each benthic group (i.e., MPB, meio- and macrofauna), by pooling together data obtained in September and March (Clarke and Warwick, 2001). To assess whether the two groups of stations identified from the cluster analysis were statistically different among each other, ANOSIM tests were performed considering such groups as the discriminating factor.

Further, variations across sampling periods (September $v s$ March) and water depths $(<20 \mathrm{~m} v s>20 \mathrm{~m})$ were investigated using two-way crossed ANOSIM tests applied on benthic diatoms, meiofauna and macrofauna datasets, separately. The same tests were applied also on normalized environmental data (sand, TOC, TN, $\mathrm{PO}_{4}{ }^{3-}$, dissolved inorganic nitrogen - DIN - as sum of all inorganic nitrogen forms, $\mathrm{Chl} a$, phaeopigments) using Euclidean distance matrixes. The outputs of ANOSIM were interpreted according to Clarke and Gorely (2006): $\mathrm{R}<0.25=$ no differences among stations/sampling periods for the considered biotic/abiotic variables; $\mathrm{R}>0.5=$ indicated some overlapping but the stations/sampling periods differed for a certain degree; $\mathrm{R}>0.75=$ the stations/sampling periods were statistically different for the considered biotic/abiotic variables. When the two-way crossed ANOSIM highlighted the presence of statistically differ- 
ent benthic communities according to the tested factors, a similarity percentage (SIMPER) analysis was carried out in order to detect which taxa were mainly responsible for the variations observed. A percentage dissimilarity cutoff of $50 \%$ was applied. Diversity indexes, cluster, ANOSIM and SIMPER analyses were carried out using the routines included in the PRIMER software ver. 5 (PRIMER-E Ldt, Plymouth, UK).

Principal Component Analysis (PCA) was carried out on the whole environmental and faunal dataset in order to visualise the trends of the main abiotic variables. After normalisation, the absolute abundances of benthic diatoms, meio- and macrofauna were also projected on the factor plane as additional variables without contributing to the results of the analysis. This can provide an insight into the possible influence of the environmental variables upon each benthic group (STATISTICA 7).

To highlight interactions between biotic and abiotic variables a Spearman's rank correlation analysis $(\mathrm{R})$ was performed using STATISTICA $7(\mathrm{P}<0.05 ; \mathrm{P}<0.01 ; \mathrm{P}<0.001)$.

\section{RESULTS}

\section{Environmental variables}

In September, bottom temperatures varied from 11.9 ${ }^{\circ} \mathrm{C}$ (St. C04) to $23.4{ }^{\circ} \mathrm{C}$ (St. C01), with higher values at the shallower stations and colder conditions at the deeper ones. By contrast, in March, bottom temperatures were quite homogeneous $\left(\sim 10^{\circ} \mathrm{C}\right)$ within the entire 10-pointstation grid.

At all stations, the uppermost sediment layer was mainly characterised by the mud fraction (as the sum of silt and clay percentages) during both study periods (Tab. 1). In September, a lower percentage of mud was observed inshore, especially at St. C01, where the minimum was reached (55.2\%). At the offshore stations, muddier sediments were found, particularly at St. B04, where the percentage of mud exceeded 98\%. In March, overall similar grain-size features were observed with an increase of mud percentage from the shallower stations towards the open sea. Surface mud fractions ranged from a minimum of $59.7 \%$ at St. D02 to a maximum of $98.5 \%$ at St. B04. According to Shepard's (1954) classification, the sediment was clayey silt at all stations, with the exception of St. C01 and St. D02 where it was sandy silt in both sampling periods. TOC content varied between $1.71 \mathrm{mg} \mathrm{C} \mathrm{g}^{-1}$ (St. C01) and $13.20 \mathrm{mg} \mathrm{C} \mathrm{g}^{-1}$ (St. C03) in September and between $3.78 \mathrm{mg} \mathrm{C} \mathrm{g}^{-1}$ (St. D02) and $12.06 \mathrm{mg} \mathrm{C} \mathrm{g}^{-1}$ (St. B04) in March. TN content ranged from $0.14 \mathrm{mg} \mathrm{N} \mathrm{g}^{-1}$ (St. C01) to $1.58 \mathrm{mg} \mathrm{N} \mathrm{g}^{-1}$ (St. C03) in September and from $0.51 \mathrm{mg} \mathrm{N}$ $\mathrm{g}^{-1}$ (St. D02) to $1.70 \mathrm{mg} \mathrm{N} \mathrm{g}^{-1}$ (St. B04) in March. Coastal stations had lower TOC and TN contents than the offshore ones, and similar values occurred in the two study periods.
DIN concentrations measured in the pore water of the top sediment layer varied from $24.89 \mu \mathrm{M}$ (St. D04) to 107.97 $\mu \mathrm{M}$ (St. C02) in September, and from $5.84 \mu \mathrm{M}$ (St. D02) to $38.70 \mu \mathrm{M}$ (St. B02) in March. DIN concentrations generally decreased from the inshore stations towards the open sea during both study periods. Pore water $\mathrm{PO}_{4}{ }^{3-}$ concentrations ranged from $0.80 \mu \mathrm{M}$ (St. C02) to $1.63 \mu \mathrm{M}$ (St. D04) in September, and from $0.57 \mu \mathrm{M}$ (St. C03) to $1.52 \mu \mathrm{M}$ (St. D04) in March. Unlike DIN values, phosphate concentrations increased from the coast towards the open sea during both periods. The lowest $\mathrm{SiO}_{3}{ }^{2-}$ concentrations were observed inshore (51.88 $\mu \mathrm{M}$ at St. C01 in September; 7.16 $\mu \mathrm{M}$ at St. D02 in March), whereas the highest values occurred at the offshore stations $(148.11 \mu \mathrm{M}$ at St. C03 in September; $142.04 \mu \mathrm{M}$ at St. B04 in March). In September, Chl $a$ values ranged from $0.29 \mu \mathrm{g} \mathrm{g}^{-1}$ (St. C01) to $2.62 \mu \mathrm{g}$ $\mathrm{g}^{-1}$ (St. B02). With the exception of St. C01, the shallower stations had the highest $\mathrm{Chl} a$ sedimentary contents, whereas lower values were observed offshore. Phaeopigments concentrations increased from the coast towards the open sea, with the lowest value observed at St. C01 (3.68 $\left.\mu \mathrm{g} \mathrm{g}^{-1}\right)$ and the highest at St. B04 $\left(23.24 \mu \mathrm{g} \mathrm{g}^{-1}\right)$. In March Chl $a$ varied between $0.53 \mu \mathrm{g} \mathrm{g}^{-1}$ (St. C03) and $2.61 \mu \mathrm{g}$ $\mathrm{g}^{-1}$ (St. B04), whereas phaeopigments between $8.51{\mu \mathrm{g} \mathrm{g}^{-1}}^{-1}$ (St. C01) and $19.75 \mu \mathrm{g} \mathrm{g}^{-1}$ (St. B04) (Tab. 1).

\section{Microphytobenthos}

In September, microphytobenthic abundance ranged from $9900 \pm 424$ cells cm${ }^{-3}$ at St. C01 to $86400 \pm 16971$ cells cm$~^{-3}$ at St. D02 whereas in March the lowest value was recorded at St. B02 $\left(18900 \pm 5515\right.$ cells cm$\left.^{-3}\right)$, and the highest at St. C01 $\left(111600 \pm 23759\right.$ cells $\left.\mathrm{cm}^{-3}\right)$. During both sampling periods, total MPB abundance was not correlated with water depth.

The microphytobenthic community was mainly composed of diatoms (Fig. 2 a,b). In September, Bacillariophyta represented $45.5 \%$ of the total microalgal abundance at St. C01, whereas their RA reached $96.2 \%$ at St. D02 (Fig. 2a). Undetermined Phytoflagellates and resting cells (spores and cysts) were found at all stations, whereas Chlorophyceae were observed only at St. D03 and Cyanophyceae only at St. C03 and D03. In March, diatoms relative abundance ranged from $66.7 \%$ at St. B02 to $94.6 \%$ at St. C01. Relatively high percentages of Phytoflagellates were observed at St. B04 (11.4\%) and D03 (10.0\%). Undetermined spores were more abundant at St. B02, C02 and D03 than at all the other stations (Fig. 2b, in legend as undet. spores). Since, besides Bacillariophyta, the specimens belonging to other groups remained mostly undetermined at higher taxonomic level, further analyses were focused only on the benthic diatom community. Pooling the data together from all stations, 17 diatom genera were observed in September and 16 in March. In September, Paralia was the dominant genus, followed by Nitzschia, Navicula and Gyrosigma. In March, the 
planktonic genus Skeletonema was very abundant at St. C01 and, overall, its abundance was higher at stations closest to the coast. Paralia was the second most abundant genus, fol- lowed by Navicula and Diploneis (Tab. 2). Paralia sulcata was the most abundant diatom species in September, when reached a maximum of 33600 cells $\mathrm{cm}^{-3}$ at St. C04.

\section{September 2010}

Microphytobenthos

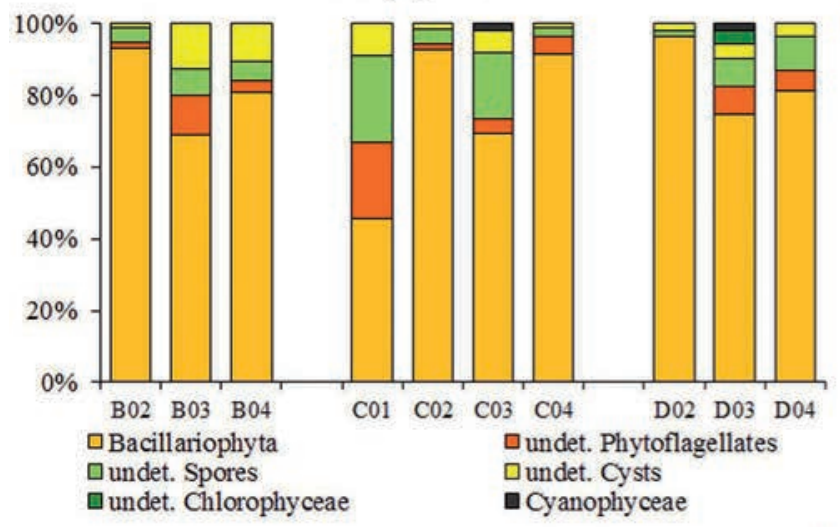

a)

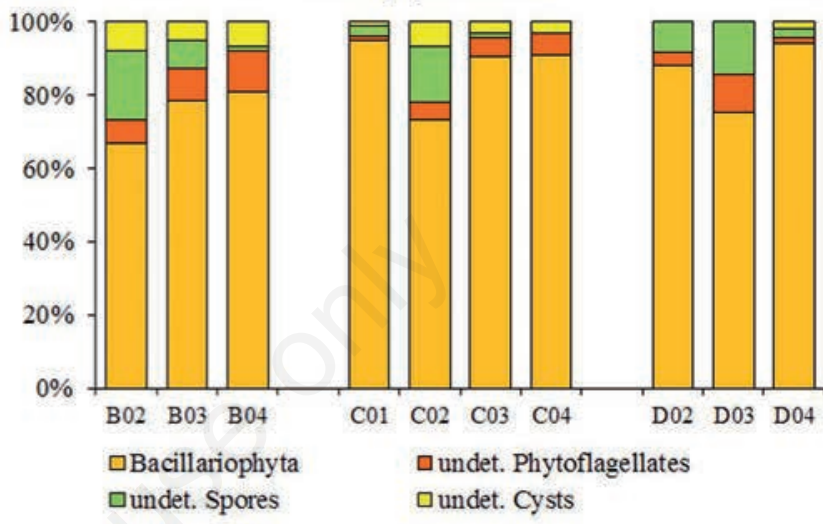

Meiofauna

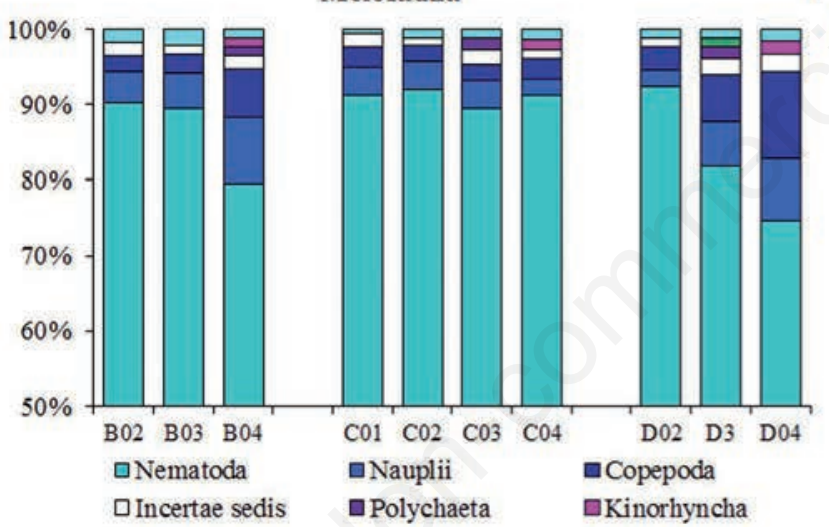

c)

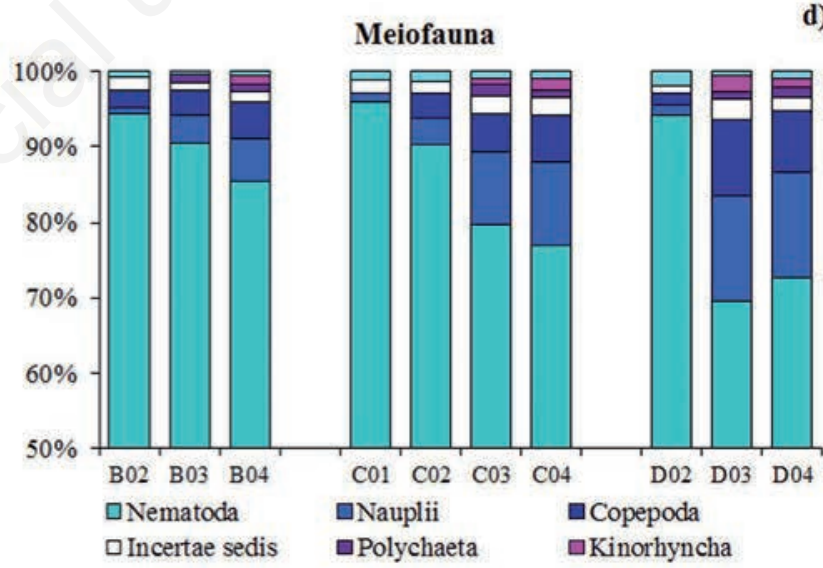

e)
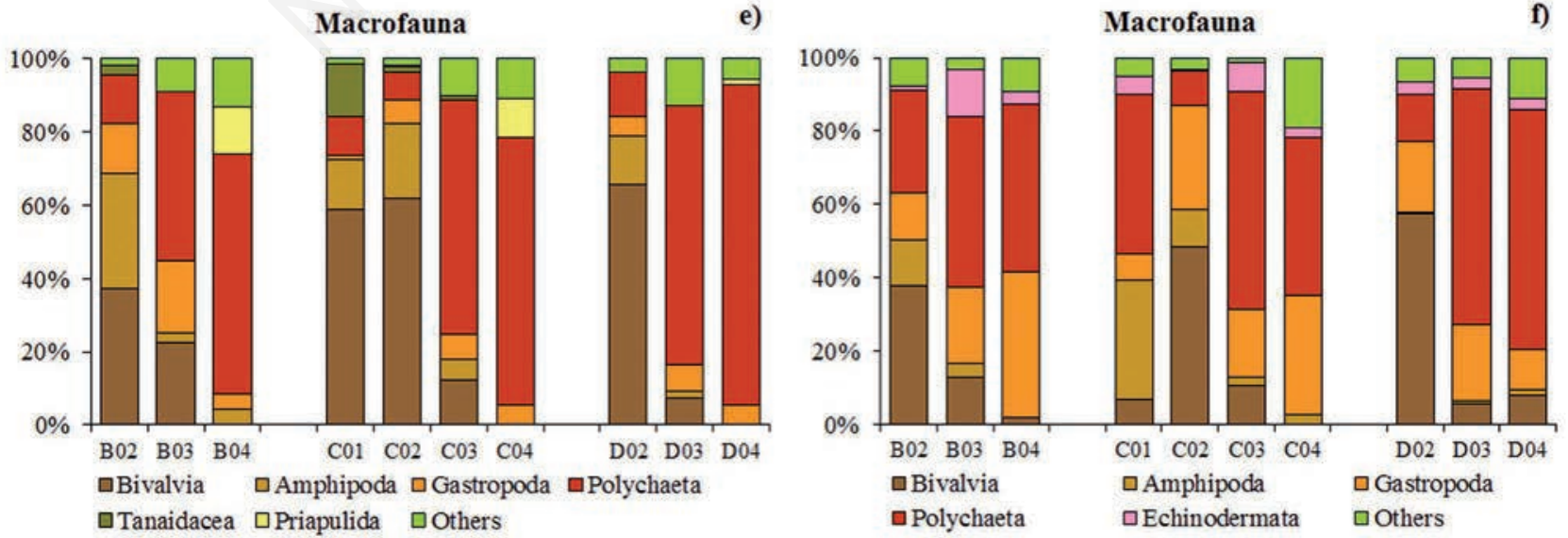

Fig. 2. Relative abundance of microphytobenthos (a, b), meiofauna (c, d) and macrofauna (e, f) at each station along the 10-pointstation grid in September 2010 (left side) and March 2011 (right side). For meiofauna, taxa representing $<1 \%$ of the total abundance are included in the group Others and a cut-off at $50 \%$ on Y-axis was applied. Macrofauna taxa representing $<10 \%$ of the total abundance at all stations are included in the group Others. 
Rhopalodia gibba was found only at St. D02, C02 and B02, specifically in those stations where the depth ranged from 18.8 to $20.8 \mathrm{~m}$. Gyrosigma acuminatum and G. spencerii reached higher abundance at stations closest to the coast. In March, the planktonic species Skeletonema costatum and the tychopelagic Paralia sulcata reached the highest abundance followed by the benthic species Diploneis bombus. The diatom community was more diverse in September than in March (Tab. 4). In September, higher d and H'values were observed at St. D02 ( $\left.d=2.207 ; H^{\prime}=2.782\right)$. The dominance of Paralia sulcata at St. C04 (87.5\% of the total diatom abundance) explained the highest $\lambda$ observed at this station (0.770). In March, the highest diversity was recorded at St. B02 $\left(\mathrm{H}^{\prime}=2.070\right)$ and the highest richness at St. D04 $(d=1.289)$. The highest $\lambda(0.891)$ was obtained at St. C01 due to the dominance of Skeletonema costatum, which in this station accounted for $94.3 \%$ of the whole diatom community. The complete list of diatom species is reported in Supplementary Tab. 1.

\section{Meiofauna}

In September, meiofauna ranged from $269.5 \pm 141.3$ to $951.2 \pm 464.8$ ind. $10 \mathrm{~cm}^{-2}$ at St. C03 and St. D02, respectively. In March, values varied from $376.8 \pm 113.6$ ind. 10 $\mathrm{cm}^{-2}$ at St. B02 to $1030.9 \pm 70.0$ ind. $10 \mathrm{~cm}^{-2}$ at St. B03. During both sampling periods, total abundance did not vary among inshore and offshore stations. A total of 16 major groups were identified, with nematodes being dominant in both study periods and at all stations (Fig. 2 c,d). In September, these organisms represented $74.6 \%$ of the total meiofaunal abundance at St. D04 and up to $92.4 \%$ at St. D02, whereas in March their relative abundance varied from $69.6 \%$ (St. D03) to $96.0 \%$ (St. C01). Copepods (adults and juvenile stages) represented the second most abundant taxon during both periods of the study and were more abundant offshore than inshore. Their relative abundances ranged, in fact, from 5.3\% (St. D02) to 19.8\% (St. D04) in September and from 1.1\% (St. C01) to $24.1 \%$ (St. D03) in March. The other main groups represented minor fractions of the whole community: Polychaeta and Kinorhyncha were observed only at stations with a depth $>20 \mathrm{~m}$ during both study periods. Their relative abundances, in fact, did not exceed 1.6\% (St. D03, September) and $2.2 \%$ (St. D03, March) of the total assemblage, respectively. Undetermined organisms (Fig. 2 c,d; in legend as Incertae sedis) were observed at all stations in percentages generally $<3 \%$ both in September and March. During both sampling periods meiofauna resulted more diverse at the offshore stations than at the inshore ones, with the latter more strongly dominated by nematodes. The number of taxa varied, in fact, from 4 (St. C01) to 11 (St. B04) in September. In March, the lowest number of taxa (4) was recorded at St. C01, and the highest (9) was observed at different depths (St. C03, St. C04 and St. D02).

\section{Macrofauna}

Shallower stations (B02, C01, C02 and D02) were characterised by higher macrofaunal abundance than the deeper ones during both sampling periods. Values ranged from $76.7 \pm 30.6$ ind. $\mathrm{m}^{-2}$ (St. B04) to $5166.7 \pm 1361.2$ ind.

Tab. 2. Abundance, expressed as cells $\mathrm{cm}^{-3}$, of the first ten dominant diatom species during the two periods of the study.

\begin{tabular}{|c|c|c|c|c|c|c|c|c|c|c|}
\hline & B02 & B03 & B04 & C01 & $\mathrm{CO2}$ & $\mathrm{CO3}$ & $\mathrm{CO4}$ & D02 & D03 & D04 \\
\hline \multicolumn{11}{|l|}{ September 2010} \\
\hline Paralia sulcata & 1800 & 2400 & 9900 & 300 & 0 & 2100 & 33600 & 0 & 7500 & 9000 \\
\hline Rhopalodia gibba & 900 & 0 & 0 & 0 & 4200 & 0 & 0 & 10800 & 0 & 0 \\
\hline Nitzschia fasciculata & 2700 & 0 & 0 & 0 & 600 & 0 & 0 & 10200 & 0 & 0 \\
\hline Nitzschia lorenziana & 2400 & 600 & 0 & 0 & 900 & 600 & 0 & 3900 & 300 & 0 \\
\hline Navicula directa & 1800 & 0 & 0 & 0 & 2700 & 0 & 0 & 2400 & 0 & 0 \\
\hline Bacillaria paxillifera & 0 & 0 & 0 & 0 & 0 & 0 & 0 & 6300 & 0 & 0 \\
\hline Gyrosigma spencerii & 3300 & 0 & 0 & 0 & 3000 & 0 & 0 & 0 & 0 & 0 \\
\hline Gyrosigma acuminatum & 1200 & 600 & 300 & 600 & 0 & 2100 & 0 & 0 & 300 & 300 \\
\hline Pleurosigma aestuarii & 0 & 0 & 0 & 0 & 2700 & 0 & 0 & 2400 & 0 & 0 \\
\hline Nitzschia sigma & 0 & 0 & 0 & 0 & 900 & 0 & 0 & 3000 & 0 & 0 \\
\hline \multicolumn{11}{|l|}{ March 2011} \\
\hline Skeletonema costatum & 4800 & 1800 & 0 & 99600 & 8700 & 0 & 3000 & 20700 & 300 & 3000 \\
\hline Paralia sulcata & 0 & 8100 & 16200 & 0 & 1500 & 18000 & 16200 & 0 & 7500 & 39300 \\
\hline Gyrosigma spencerii & 900 & 300 & 0 & 300 & 300 & 0 & 0 & 600 & 0 & 0 \\
\hline Ceratoneis closterium & 0 & 0 & 0 & 900 & 0 & 0 & 0 & 900 & 0 & 300 \\
\hline Rhopalodia gibba & 300 & 0 & 0 & 300 & 0 & 0 & 0 & 1500 & 0 & 0 \\
\hline Nitzschia tryblionella & 600 & 0 & 600 & 0 & 300 & 0 & 0 & 0 & 300 & 0 \\
\hline Entomoneis alata & 0 & 0 & 0 & 300 & 0 & 900 & 0 & 0 & 0 & 0 \\
\hline Thalassionema nitzschioides & 0 & 0 & 0 & 0 & 0 & 1200 & 0 & 0 & 0 & 0 \\
\hline
\end{tabular}


$\mathrm{m}^{-2}$ (St. C01) and from $123.3 \pm 110.2$ ind. $\mathrm{m}^{-2}$ (St. C04) to $1080.0 \pm 475.7$ ind. $\mathrm{m}^{-2}$ (St. C02) in September and March, respectively. Overall, the abundance in September was generally higher than in March, particularly at the shallower stations.

Macrofaunal taxa representing $<10 \%$ of the total abundance (e.g., anthozoans, copepods, echinoderms, priapulids, sipunculids) were pooled in Others (Fig. 2 e,f). In September, bivalves and amphipods were more abundant at the inshore stations than at the offshore ones, representing $65.6 \%$ at St. D02 and 31.4\% at St. B02, respectively while being completely absent at St. B04, C04 and D04 (bivalves) and at St. C04 and D04 (amphipods). In both sampling periods, polychaetes gradually became the dominant group with increasing water depth. The relative abundance varied, in fact, from $7.7 \%$ (St. C02) to $87.5 \%$ (St. D04) and from 9.3\% (St. C02) to 65.1\% (St. D04) in September and March, respectively. Priapulids were observed only offshore. In March, the decreasing percentage of bivalves from the coast towards the open sea was not clear as that in September. Both in September and March the inshore stations were dominated by the bivalve Corbula gibba, which reached the highest abundance at the shallowest St. C01 (2540.0 ind. $\mathrm{m}^{-2}$ ) in September (Tab. 3). The offshore stations were mainly characterised by the polychaete Sternaspis scutata during both sampling periods (up to 83.3 ind. $\mathrm{m}^{-2}$ at St. B03 and C03 in March). In September also the second dominant species, the amphipod Ampelisca spinipes, showed the highest abundance inshore (up to 623.3 ind. $\mathrm{m}^{-2}$ at St. B02). In March, the inshore stations were also characterised by the presence of the bivalve Tellimya ferruginosa and the gastropod Turritella communis with the highest values observed at St. D02 (313.3 ind. $\mathrm{m}^{-2}$ ) and C02 (200.0 ind. $\mathrm{m}^{-2}$ ), respectively, and the offshore ones by the gastropod Hydrobia acuta (86.7 ind. $\mathrm{m}^{-2}$ at St. B03). In September, the highest diversity was observed at St. D02 $\left(\mathrm{H}^{\prime}=2.520\right)$, which also had the second highest richness $(\mathrm{d}=6.561)$. The lowest values of both H' (1.636) and d (2.190) were observed at St. D04 in correspondence with the highest dominance $(\lambda=0.360)$. In March, the maximum diversity $\left(H^{\prime}=2.866\right)$ and the second lowest dominance value $(\lambda=0.105)$ were observed at St. C01. The lowest richness $(\mathrm{d}=2.492)$ and diversity $\left(H^{\prime}=2.055\right)$ were observed at $\mathrm{St}$. C04 in correspondence with the maximum dominance $(\lambda=0.186)$ (Tab. 4). The complete list of the observed macrofaunal organisms is reported in Supplementary Tab. 2.

\section{Statistical analyses}

Overall, the cluster analysis performed on the datasets of each benthic community separately showed the presence of distinct assemblages according to the different depth. On the contrary, since the subclusters comprised indiscriminately samples of September and March, the variability due to the different period seemed less important (Fig. 3). The results of the ANOSIM test indicated that, for all the three benthic communities, the groups identified by the cluster analysis were statistically different among each other (benthic diatoms, $\mathrm{R}=0.818$; meiofauna, $\mathrm{R}=0.706$; macrofauna, $\mathrm{R}=0.922$ ). Focusing on benthic diatoms, two clusters were

Tab. 3. Abundances, expressed as ind. $\mathrm{m}^{-2}$, of the first ten dominant macrobenthic species during both periods of the study.

\begin{tabular}{lcccccccccc} 
& $\mathbf{B 0 2}$ & $\mathbf{B 0 3}$ & $\mathbf{B 0 4}$ & $\mathbf{C 0 1}$ & $\mathbf{C 0 2}$ & $\mathbf{C 0 3}$ & $\mathbf{C 0 4}$ & $\mathbf{D 0 2}$ & $\mathbf{D 0 3}$ & $\mathbf{D 0 4}$ \\
September 2010 & & & & & & & & & \\
Corbula gibba & 523.3 & 0.0 & 0.0 & 2540.0 & 970.0 & 0.0 & 0.0 & 626.7 & 0.0 & 0.0 \\
Ampelisca spinipes & 623.3 & 0.0 & 0.0 & 516.7 & 376.7 & 0.0 & 0.0 & 83.3 & 0.0 & 0.0 \\
Apseudopsis latreillei & 50.0 & 0.0 & 0.0 & 743.3 & 30.0 & 3.3 & 0.0 & 0.0 & 0.0 & 0.0 \\
Tellimya ferruginosa & 190.0 & 76.7 & 0.0 & 40.0 & 26.7 & 30.0 & 0.0 & 166.7 & 6.7 & 0.0 \\
Nucula sulcata & 53.3 & 0.0 & 0.0 & 163.3 & 70.0 & 0.0 & 0.0 & 56.7 & 0.0 & 0.0 \\
Turritella communis & 200.0 & 0.0 & 0.0 & 0.0 & 83.3 & 3.3 & 0.0 & 43.3 & 0.0 & 0.0 \\
Sternaspis scutata & 43.3 & 43.3 & 10.0 & 0.0 & 20.0 & 80.0 & 16.7 & 10.0 & 40.0 & 20.0 \\
Amphictene auricoma & 0.0 & 0.0 & 0.0 & 216.7 & 20.0 & 0.0 & 0.0 & 6.7 & 0.0 & 3.3 \\
Lumbrineris adriatica & 63.3 & 3.3 & 0.0 & 136.7 & 16.7 & 0.0 & 0.0 & 13.3 & 0.0 & 3.3 \\
Hydrobia acuta & 73.3 & 70.0 & 3.3 & 43.3 & 3.3 & 16.7 & 6.7 & 3.3 & 3.3 & 3.3 \\
March 2011 & & & & & & & & & \\
Corbula gibba & 190.0 & 0.0 & 0.0 & 10.0 & 310.0 & 0.0 & 0.0 & 96.7 & 0.0 & 0.0 \\
Tellimya ferruginosa & 0.0 & 53.3 & 3.3 & 40.0 & 40.0 & 30.0 & 0.0 & 313.3 & 16.7 & 6.7 \\
Turritella communis & 56.7 & 0.0 & 6.7 & 0.0 & 200.0 & 10.0 & 0.0 & 110.0 & 6.7 & 3.3 \\
Hydrobia acuta & 13.3 & 86.7 & 66.7 & 23.3 & 20.0 & 40.0 & 40.0 & 20.0 & 60.0 & 16.7 \\
Sternaspis scutata & 66.7 & 83.3 & 26.7 & 0.0 & 3.3 & 83.3 & 30.0 & 13.3 & 63.3 & 10.0 \\
Ampelisca spinipes & 43.3 & 13.3 & 0.0 & 190.0 & 110.0 & 0.0 & 0.0 & 3.3 & 3.3 & 0.0 \\
Nucula sulcata & 23.3 & 0.0 & 0.0 & 0.0 & 63.3 & 0.0 & 0.0 & 113.3 & 0.0 & 0.0 \\
Caulleriella multibranchis & 0.0 & 20.0 & 6.7 & 3.3 & 10.0 & 0.0 & 3.3 & 0.0 & 53.3 & 60.0 \\
Oestergrenia thomsonii & 3.3 & 53.3 & 6.7 & 0.0 & 3.3 & 20.0 & 3.3 & 33.3 & 10.0 & 6.7 \\
Lumbrineris adriatica & 3.3 & 6.7 & 0.0 & 63.3 & 20.0 & 0.0 & 0.0 & 23.3 & 3.3 & 3.3 \\
\hline
\end{tabular}



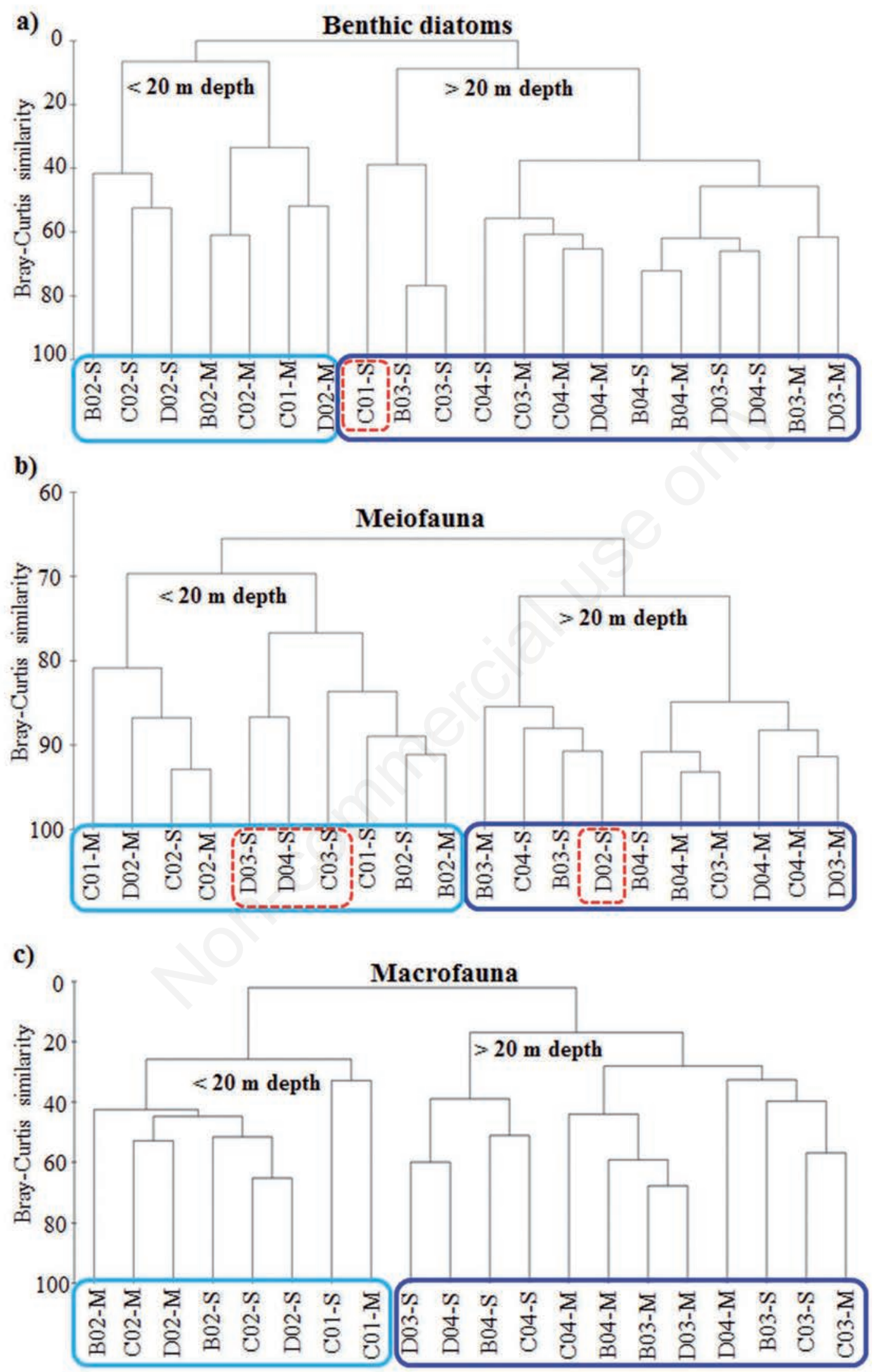

Fig. 3. Cluster analysis based on the abundances of benthic diatoms (a), meiofauna (b) and macrofauna (c) exploring for variations among stations and sampling periods. S, September 2010; M, March 2011. In red circles the outliers. 
discriminated by a depth threshold of $20 \mathrm{~m}$ : a cluster including all station at $>20 \mathrm{~m}$ (plus St. C01 in September), and a cluster including all stations at $<20 \mathrm{~m}$ depth (Fig. 3a). The cluster analysis carried out for meiofauna grouped again stations in two clusters. Though the discrimination according to water depth was less clear than the one observed for diatoms, a group included the majority of offshore stations (depth $>20 \mathrm{~m}$ ) and the other included the majority of inshore ones (depth $<20 \mathrm{~m}$ ) (Fig. 3b). The cluster analysis carried out for macrofauna grouped the stations in two groups discriminated again by the threshold depth of $20 \mathrm{~m}$ (Fig. 3c).

Following the results of the cluster analysis, two-way crossed ANOSIM tests were carried out to test for differences in the composition of diatom, meiofauna and macrofauna communities, using sampling periods and water depth (i.e., $>20 \mathrm{~m}$ and $<20 \mathrm{~m}$ depth) as discriminating factors. The outputs on the diatom community (Tab. 5) revealed water depth as the unique factor able to explain significant community variations, while the sampling period seemed to not exert any kind of effect. The SIMPER analysis revealed that the dissimilarity between inshore and offshore microalgal assemblages (depth $<20 \mathrm{~m} v s$ depth $>20 \mathrm{~m}$ ) was mainly due to the presence of Paralia sulcata (Contrib.\%=7.05) and Skeletonema costatum (Contrib. $\%=5.67)$ : the first was more abundant offshore while the second species proliferated at shallower depth (Tab. 6). Meiofaunal communities did not differ significantly be- tween either sampling times or water depth, whereas macrofauna community composition varied significantly among both sampling periods and water depth (Tab. 5).

The SIMPER analysis on macrofauna showed that the main differences among sampling periods (irrespectively of sampling station) were due to the higher abundances of the dominant species in September (Tab. 7). On the other hand, the dissimilarity between inshore and offshore communities (irrespectively of the sampling period) were mainly due to Corbula gibba (Contrib.\%=4.77), Ampelisca spinipes (Contrib.\%=3.80) and Nucula sulcata (Contrib. $\%=3.10$ ), which mainly characterised inshore stations, while polychaetes like Tharyx spp. (Contrib.\%=1.71) and Sternaspis scutata (Contrib.\%=1.42) proliferated offshore (Tab. 7). The results of the two-way crossed ANOSIM test performed on abiotic parameters showed that the environmental assets of the investigated stations did not vary from September to March $(\mathrm{R}=0.332)$, whereas in both sampling periods a significant variation was detected between the cluster that included stations at $<20 \mathrm{~m}$ depth and that with stations at $>20 \mathrm{~m}$ depth (Tab. 5).

In the PCA two principal components (factors) were identified (eigenvalue $>1$ ) which together explained $73.72 \%$ of the total variance, whereas the first and second factors explained $56.07 \%$ and $17.65 \%$ of the total variance, respectively (Fig. 4a). Sand percentage, depth, DIN and TOC mostly contributed to the first factor, whereas Chl $a$ was the most important contributor to the second factor.

Tab. 4. Diversity indexes for benthic diatoms and macrofauna in September 2010 and March 2011.

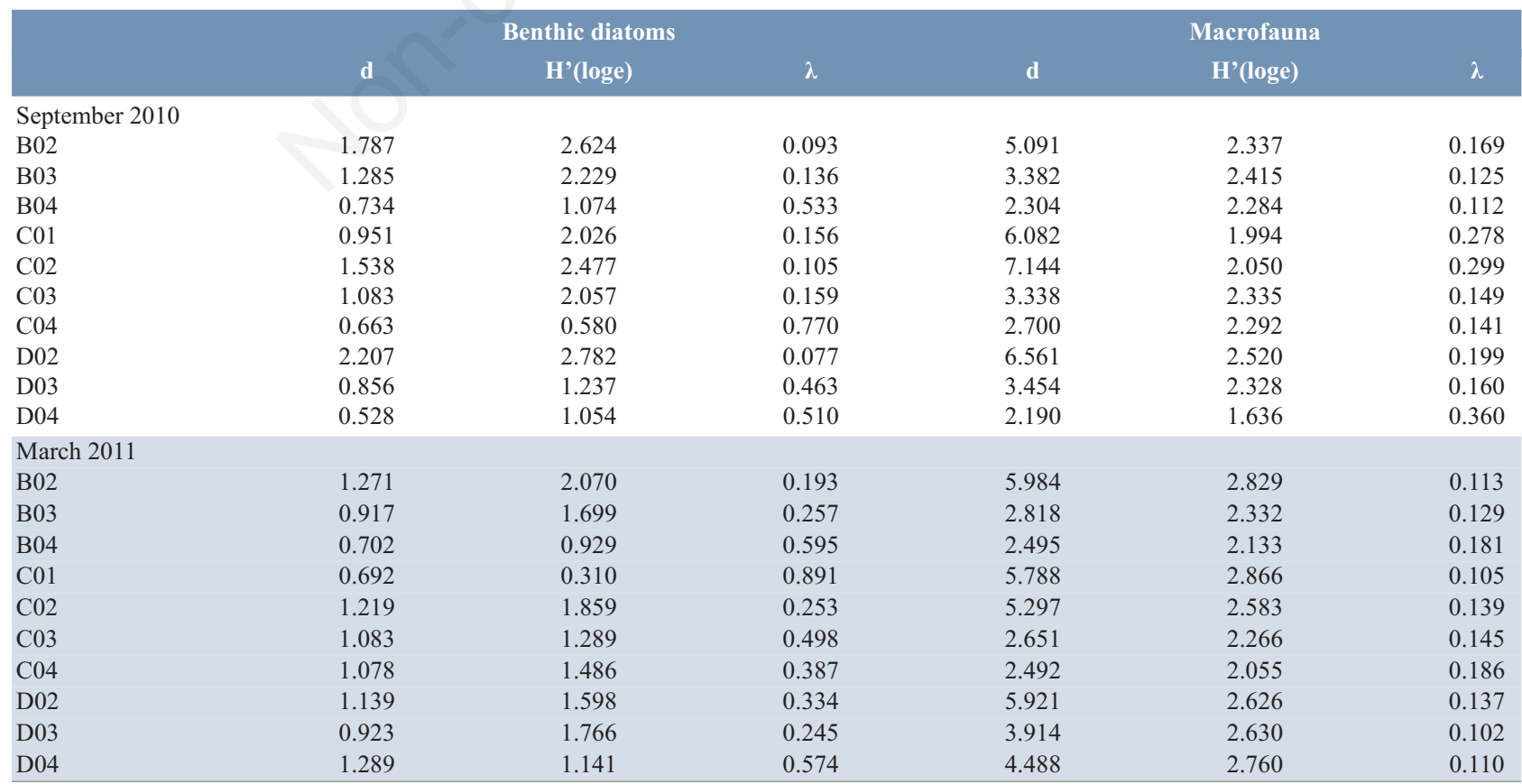

$\mathrm{d}$, richness; H', diversity; $\lambda$, dominance. 
Since the ANOSIM tests revealed that the sampling period did not explain significant proportions of community variations, all of the samplings stations were plotted on the PCA factor-plane 1x2, which grouped the stations according to their environmental conditions (Fig. 4b). Two distinct groups were recognized with inshore $(<20 \mathrm{~m})$ and offshore $(>20 \mathrm{~m})$ stations in the right and left half of the plot, respectively.

\section{DISCUSSION}

\section{Environmental characteristics of the sediments in the study area}

During both study periods, the main chemical parameters and the sediment grain-size varied remarkably within the 10-point-station grid, suggesting the presence of two different sedimentary matrices, which most likely led to the development of different benthic communities. Mud prevailed at all stations, but the percentage of sand inshore was higher than the one offshore. As outlined by Frontalini et al. (2011), this result suggests that the presence of more dynamic hydrological conditions at the inshore stations likely favoured the accumulation of poorly sorted and deposited fine-grained material offshore. As expected, the different grain-size had also an influence on the TOC sedimentary content: the negative correlation between sand percentage and TOC content in September $(n=10 ; R=-$ $0.68, \mathrm{P}<0.05)$ and March $(\mathrm{n}=9 ; \mathrm{R}=-0.97, \mathrm{P}<0.001)$, suggests that the muddier sediment offshore exerted a greater retention of sediment-bound organic matter, which in turn could have consequences on the food availability for benthic faunas (Semprucci et al. 2010, 2013).
In September, higher concentrations of DIN, negatively correlated with water depth $(n=9 ; R=-0.82, P<0.01)$ were observed at the shallower stations than offshore. Although correlations do not allow to infer about cause-effect relationships, the presence of a decreasing pattern of DIN pore water concentrations with increasing water depth in September, early observed by Frontalini et al. (2011) for nutrient concentrations in the water column, suggests that eventual discharge activities or runoff occurring along the coasts in late summer (i.e., September) are rapidly diluted offshore. In March, the lack of such a coast-to-offshore pattern in DIN pore water concentrations could be probably due to the presence of more dynamic hydrological conditions in late winter, possibly caused by bad weather conditions, which could have favoured the spreading and dilution of the terrestrial outfalls even inshore.

\section{Benthic communities}

This study was specifically designed in order to include not only locations along the strictly coastal belt but

Tab. 5. Outputs of the two-way crossed ANOSIM test performed using the sampling period (September $v s$ March) and water depths $(<20 \mathrm{~m} v s>20 \mathrm{~m})$ as factors. Statistically significant results according to Clarke and Gorely (2006) are underlined.

\begin{tabular}{lcc}
$\begin{array}{lc}\text { Two-way crossed ANOSIM } \\
\text { Factor }\end{array}$ & $\begin{array}{c}\text { R } \\
\text { Period }\end{array}$ & $\begin{array}{c}\text { R } \\
\text { Depth }\end{array}$ \\
Benthic diatoms & 0.334 & $\underline{0.835}$ \\
Meiofauna & 0.153 & 0.46 \\
\hline Macrofauna & $\underline{0.611}$ & $\underline{0.976}$ \\
Abiotic parameters & 0.332 & $\underline{0.673}$ \\
\hline
\end{tabular}

Tab. 6. Species contributions to average dissimilarity between benthic diatom communities at the inshore (depth $<20 \mathrm{~m})$ and offshore stations (depth $>20 \mathrm{~m}$ ). Cut-off percentage $50 \%$.

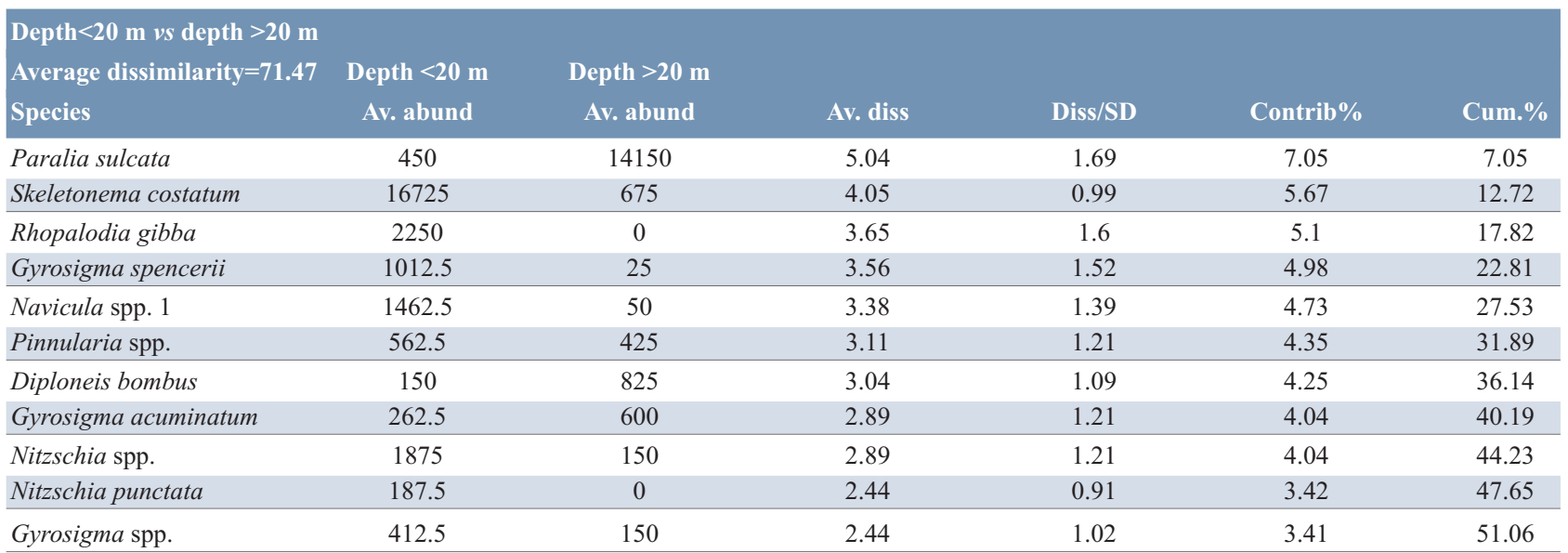

Av. abund, average abundance; Av. diss, average dissimilarity; Contrib\%, species contribution to the average dissimilarity between groups; Cum. $\%$, cumulative percentage. 
also offshore, i.e., even at $>12 \mathrm{nmi}$ from the coastline. This approach, although partially biased by pseudo-replication at the level of station, allowed us to provide some insights on the environmental status of a marine region generally neglected by monitoring plans. Indeed, although offshore stations are included as putative targets for monitoring protocols of the MSFD, there are still many knowledge gaps on these systems. In fact, according to the recently published viewpoint on the MSFD complementary approach for the assessment of pressures, knowledge and data gaps in Southern European Seas (Crise et al., 2015), most countries reported significant lack of data on biodiversity acquired offshore (i.e,. beyond $12 \mathrm{nmi}$ seaward from the baseline). Although a temporal variation was expected comparing the chosen sampling periods, the results of both the cluster analysis and the two-way crossed ANOSIM suggest that the spatial variability among stations exceeded the temporal one, revealing the presence of different environmental contexts that, to some extent, were maintained over the seasons. MPB depend upon several factors, such as light penetration, sediment grain-size, coastal hydrodynamics, nutrient availability, grazing pressure, contamination and temperature. The synergistic effects of all these abiotic variables select the composition and abundance of the microphytobenthic community. Since the 10-point-station grid covered a quite large area, with different physical features at each station, the resulting abundances were quite diverse among the studied stations. This was more pronounced in September, when the difference between values inshore and offshore reached up to one order of magnitude (9900 \pm 424 cells cm ${ }^{-3}$ at C01 vs $86400 \pm 16971$ cells cm$^{-3}$ at St. D02). The MPB abundance was particularly low at St. C01 most likely because of the high percentage of sand in this station (44.8\%). In fact, coarse-grained sediments, which are typically characterised by high hydrodynamism with frequent sediment resuspension, do not allow the establishment of an epipelic MPB community. In more sublittoral areas, at water depths comprised between 18 and $20 \mathrm{~m}$ (i.e., St. B02, C02 and D02), muddier sediments associated with lower hydrodynamism enabled the presence of abundant microalgal assemblages, in particular in September. Conversely, at the offshore stations (St. B03, B04, etc.), deeper depths and the consequent low light availability at the sea bottom probably limited the MPB proliferation.

Although generally benthic diatoms are characterised by relevant seasonal changes (summer vs winter assemblages, each characterised by typical genera and species, Cibic et al., 2012), in this study significant temporal variability in the composition of microalgae was not highlighted (two-way crossed ANOSIM analysis; $\mathrm{R}<0.5$ ). Interestingly, the discovery of obligate benthic diatoms living at depths of about $50 \mathrm{~m}$ substantially extends the known depth range of these primary producers, which, in turn, could hold significant implications for our knowledge and estimates of oceanic productivity and biogeochemical cycling. The depth and light limits of benthic microalgae have been, in fact, very poorly investigated to date: few measurements of benthic microalgal production below 20 $\mathrm{m}$ depth, very few records of benthic microalgal $\mathrm{Chl} a$ (combined with microscopic observations of viable benthic diatom assemblages) at depths below $60 \mathrm{~m}$, and only 2 reports from below $100 \mathrm{~m}$ worldwide were published before the year 2000 (Cahoon, 1999). Recently, the presence of live active diatoms in sediments at depths down to 191
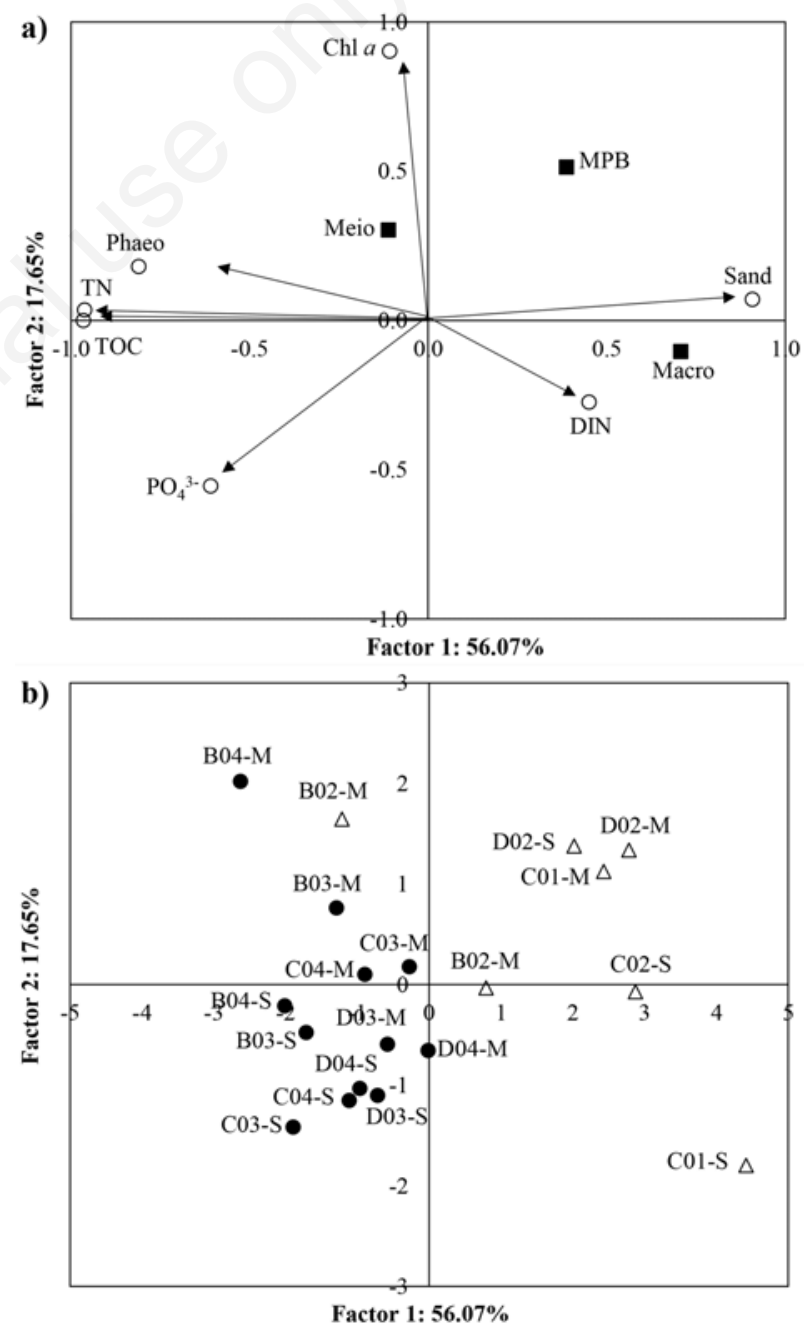

Fig. 4. PCA ordination diagram based on the selected variables (a); TOC, total organic carbon; TN, total nitrogen; DIN, dissolved inorganic nitrogen; Phaeo, phaeopigments; MPB, microphytobenthos; Meio, meiofauna; Macro, macrofauna. Scatter diagram plotting factors 1 and 2 of sampling stations (b). Station acronyms as in Fig. 1. S, September 2010; M, March 2011. 
$\mathrm{m}$, and at $<0.03 \%$ surface incident radiation have been documented (McGee et al., 2008). Within the 10-pointstation grid, $P$. sulcata was the most abundant species both in September and in March, thus being apparently not influenced by temporal variations as already reported in a seven-year study carried out in the Gulf of Trieste (Cibic et al., 2012). The absence of a relation between $P$. sulcata and light availability (McQuoid and Nordberg, 2003), suggests that this species is able to survive in the darkness for a long time. This is in accordance with the present study since Paralia was more abundant where the light availability was likely limited, i.e. at the offshore stations (depth $>20 \mathrm{~m}$ ). This hypothesis is partly supported by the positive correlation between Paralia abundance and water depth in both periods $(\mathrm{n}=10, \mathrm{R}=0.91, \mathrm{P}<0.001$ in September; $\mathrm{n}=10, \mathrm{R}=0.84, \mathrm{P}<0.01$ in March). In this regard it is worth mentioning that previous studies have reported that, in sciaphilous conditions, the heterotrophic utilization of dissolved organic compounds by benthic diatoms is likely to be an important survival strategy when light levels are too low for photosynthesis (Tuchman et al., 2006). In September, Gyrosigma was quite abundant inshore especially at St. B02 and St. C02 (>4500 cells $\left.\mathrm{cm}^{-3}\right)$, where the highest DIN concentrations were observed. Our results are in accordance with Hunter (2007), who reported that this genus tends to proliferate in high organic content conditions and warm water temperature. Moreover, our low Gyrosigma abundances in March could be attributed to colder temperatures and the mixing of the water column as a consequence of more frequent stochastic events. With the exception of the Gulf of Trieste and the Venice lagoon, only a few studies on natural microphytobenthic communities were carried out in the Adriatic Sea. Totti (2003) assessed the influence of the Po River outflow on the

Tab. 7. Macrofauna species contributions to average dissimilarity between the two sampling periods and at the inshore (depth $<20 \mathrm{~m}$ ) and offshore stations (depth $>20 \mathrm{~m}$ ). Cut-off percentage $50 \%$.

\begin{tabular}{|c|c|c|c|c|c|c|}
\hline $\begin{array}{l}\text { September } v \text { March } \\
\text { Average dissimilarity=72. }\end{array}$ & $\begin{array}{l}\text { September } \\
\text { Av, abund }\end{array}$ & $\begin{array}{c}\text { March } \\
\text { Av. abund }\end{array}$ & Av. diss & Diss/SD & Contrib \% & Cum.\% \\
\hline Tharvxs pp. & 36.00 & 167 & 222 & 111 & 305 & 3.05 \\
\hline Corbula gibba & 466.00 & 60.67 & 2.01 & 1.06 & 2.76 & 5.81 \\
\hline Ampelisca spinipes & 160.00 & 36.33 & 1.92 & 1.23 & 2.63 & 8.44 \\
\hline Tellimya ferruginosa & 53.67 & 50.33 & 1.88 & 1.17 & 2.58 & 11.02 \\
\hline Turritella communis & 33.00 & 39.33 & 1.79 & 1.31 & 2.46 & 13.48 \\
\hline Caulleriella multibranchis & 0.00 & 15.67 & 1.72 & 1.07 & 2.37 & 15.85 \\
\hline Polynoinae indet. & 0.00 & 11.33 & 1.67 & 1.03 & 2.30 & 18.15 \\
\hline Cirratulidae indet. & 0.33 & 7.00 & 1.47 & 0.98 & 2.02 & 20.17 \\
\hline Hydrobia acuta & 22.67 & 38.67 & 1.41 & 1.14 & 1.94 & 22.11 \\
\hline Sigalionidae indet. & 4.67 & 0.00 & 1.40 & 1.18 & 1.92 & 24.04 \\
\hline Lumbrineris adriatica & 23.67 & 12.33 & 1.35 & 1.31 & 1.86 & 25.90 \\
\hline Labidoplax thomsoni & 9.33 & 14.00 & 1.33 & 1.17 & 1.82 & 27.72 \\
\hline Nucula sulcata & 34.33 & 20.00 & 1.31 & 0.94 & 1.80 & 29.53 \\
\hline Aphroditidae indet. & 0.33 & 7.33 & 1.26 & 1.02 & 1.73 & 31.26 \\
\hline Abra prismatica & 9.67 & 0.33 & 1.18 & 1.31 & 1.62 & 32.88 \\
\hline Paradoneis lyra & 4.33 & 1.00 & 1.17 & 1.03 & 1.61 & 34.48 \\
\hline Ampelisca spp. & 13.00 & 5.67 & 1.13 & 1.05 & 1.55 & 36.03 \\
\hline Sternaspis scutata & 28.33 & 38.00 & 1.10 & 1.35 & 1.51 & 37.54 \\
\hline Nephtys spp. & 6.00 & 8.33 & 1.06 & 0.98 & 1.45 & 38.99 \\
\hline Necallianassa acanthura & 2.00 & 3.67 & 1.04 & 1.02 & 1.44 & 40.43 \\
\hline Apseudes latreillei & 82.67 & 3.33 & 1.04 & 0.86 & 1.43 & 41.86 \\
\hline Cirratulus spp. & 5.67 & 0.67 & 1.02 & 0.69 & 1.40 & 43.26 \\
\hline Heteromastus filiformis & 5.33 & 4.00 & 1.00 & 1.13 & 1.37 & 44.62 \\
\hline Maldanidae indet. & 7.33 & 7.67 & 0.99 & 0.99 & 1.36 & 45.99 \\
\hline Anadara demiri & 21.33 & 11.67 & 0.99 & 0.84 & 1.36 & 47.34 \\
\hline Priapulida indet. & 3.00 & 1.67 & 0.95 & 0.81 & 1.31 & 48.65 \\
\hline Nephtys hombergi & 5.00 & 1.00 & 0.95 & 0.74 & 1.31 & 49.96 \\
\hline Glycera tridactyla & 3.67 & 4.33 & 0.95 & 1.09 & 1.31 & 51.26 \\
\hline
\end{tabular}


microphytobenthic distribution and found that the plume, which determined marked coast-offshore gradients, influenced both the abundance and community structure. MPB were largely dominated by diatoms with both epipelic motile (Pleurosigma spp., Gyrosigma spp., Navicula spp.) and non-motile forms (Paralia sulcata). In accordance with our data, Totti (2003) also reported that offshore sediments were characterised by the dominance of the centric diatom Paralia sulcata.

For both meiofauna and macrofauna, the methodological approach adopted should be taken into account when comparisons with other surveys are made. In the present study, the upper size limit to discriminate among these two communities was $1000 \mu \mathrm{m}$, whereas in other studies this limit is lowered to $500 \mu \mathrm{m}$ (Simonini et al., 2005a; Simonini et al., 2005b; Simonini et al., 2007; Semprucci et al., 2010; Frontalini et al., 2011). Thus, the fraction of organisms with a body size varying between $500 \mu \mathrm{m}$ and $1000 \mu \mathrm{m}$ can fall within meiofauna or macrofauna according to the size limit used, consequently affecting the absolute abundances. Although our meio- and macrofauna densities were generally lower than those reported in previous works (Danovaro et al., 2000; Frontalini et al., 2011; Semprucci et al., 2010), these communities followed the same spatial variability reported by the other authors, i.e. meiofauna abundance tended to increase offshore while macrofauna showed the opposite pattern.

The meiofaunal community was dominated by nematodes and copepods, as observed in most coastal ecosystems, including the Adriatic Sea (Balsamo et al., 2010). Differently from benthic diatoms and macrofauna, the cluster analysis and the two-way crossed ANOSIM outputs did not point out the presence of distinct assemblages according to the different depth. We infer that the level of

Tab. 7. Continued from previous page.

\begin{tabular}{|c|c|c|c|c|c|c|}
\hline \multicolumn{7}{|l|}{$\begin{array}{l}\text { Depth }<20 \mathrm{~m} v \mathrm{~s} \text { depth }>20 \mathrm{~m} \\
\text { Average dissimilarity }=80.18\end{array}$} \\
\hline Corbula gibba & 658.33 & 0.00 & 3.83 & 4.54 & 4.77 & 4.77 \\
\hline Ampelisca spinipes & 243.33 & 1.39 & 3.05 & 2.70 & 3.80 & 8.58 \\
\hline Nucula sulcata & 67.92 & 0.00 & 2.49 & 2.45 & 3.10 & 11.68 \\
\hline Turritella communis & 86.67 & 2.50 & 2.16 & 1.66 & 2.69 & 14.37 \\
\hline Maldanidae indet. & 18.75 & 0.00 & 1.94 & 3.90 & 2.42 & 16.79 \\
\hline Lumbrineris adriatica & 42.50 & 1.67 & 1.84 & 2.05 & 2.29 & 19.08 \\
\hline Tellimya ferruginosa & 102.08 & 18.61 & 1.74 & 1.34 & 2.17 & 21.25 \\
\hline Anadara demiri & 41.25 & 0.00 & 1.73 & 1.45 & 2.16 & 23.41 \\
\hline Apseudes latreillei & 17.08 & 0.28 & 1.51 & 1.13 & 1.89 & 25.30 \\
\hline Clymene palermitana & 11.25 & 0.00 & 1.43 & 1.98 & 1.78 & 27.07 \\
\hline Tharyx spp. & 4.17 & 28.61 & 1.37 & 1.11 & 1.71 & 28.78 \\
\hline Cylichna cylindracea & 7.08 & 0.56 & 1.18 & 1.66 & 1.48 & 30.26 \\
\hline Glycera tridactyla & 8.33 & 1.11 & 1.14 & 1.58 & 1.42 & 31.68 \\
\hline Sternaspis scutata & 19.58 & 42.22 & 1.14 & 1.28 & 1.42 & 33.10 \\
\hline Melinna palmata & 12.08 & 0.00 & 1.08 & 0.89 & 1.35 & 34.45 \\
\hline Pectinaria auricoma & 31.67 & 0.28 & 1.08 & 1.11 & 1.34 & 35.79 \\
\hline Heteromastus filiformis & 8.75 & 1.94 & 1.07 & 1.55 & 1.33 & 37.13 \\
\hline Golfingia spp. & 6.25 & 0.28 & 1.07 & 1.52 & 1.33 & 38.46 \\
\hline Leucothoe venetiarum & 13.33 & 0.28 & 1.06 & 1.15 & 1.32 & 39.78 \\
\hline Labidoplax thomsoni & 9.58 & 13.06 & 1.04 & 1.40 & 1.30 & 41.07 \\
\hline Ampelisca spp. & 18.75 & 3.06 & 1.04 & 1.05 & 1.29 & 42.36 \\
\hline Pseudoleiocapitella fauveli & 12.08 & 0.00 & 1.00 & 1.13 & 1.25 & 43.62 \\
\hline Tellina pulchella & 7.92 & 0.00 & 1.00 & 1.16 & 1.24 & 44.86 \\
\hline Abra prismatica & 10.00 & 1.67 & 0.93 & 1.21 & 1.16 & 46.02 \\
\hline Nephtys spp. & 3.75 & 9.44 & 0.91 & 1.26 & 1.13 & 47.15 \\
\hline Caulleriella multibranchis & 1.67 & 11.94 & 0.90 & 0.96 & 1.12 & 48.26 \\
\hline Polynoinae indet. & 0.83 & 8.89 & 0.85 & 0.97 & 1.06 & 49.32 \\
\hline Timoclea ovata & 6.67 & 0.00 & 0.83 & 0.89 & 1.04 & 50.36 \\
\hline
\end{tabular}

Av. abund, average abundance; Av. diss, average dissimilarity; Contrib\%, species contribution to the average dissimilarity between groups; Cum.\%, cumulative percentage. 
taxonomic identification obtained for meiofauna may be not sufficient for detecting properly the changes induced by depth that likely were present within the 10-point-station grid. However, the different composition of the main groups observed among stations indicated the presence of a well developed assemblage, more diverse offshore compared to the poorly structured inshore community. Higher numbers of taxa were observed, in fact, at the stations with a depth $>20 \mathrm{~m}$ whereas the lowest value (4) was observed at St. C01 in both September and March. Nematodes, recognised as organisms tolerant to a wide range of stressors (Semprucci et al., 2015), exceeded 90\% of the total inshore meiofaunal community. As indicated by DIN concentrations higher at stations nearby the coast, the benthic domain was likely subjected to nutrient loads from the land. Going offshore, this influence decreased, favouring the development of less tolerant organisms such as copepods. These crustaceans, that showed higher abundances offshore, are recognized as sensitive for several environmental stressors, e.g., $\mathrm{O}_{2}$ depletion (Danovaro et al., 2004). Although a clear difference among sampling periods was highlighted for macrofauna $(\mathrm{R}=0.611)$, the different depth $(20 \mathrm{~m})$ seemed the main factor in determining the presence of distinct inshore and offshore communities as indicated by both the cluster analysis and the two-way crossed ANOSIM $(\mathrm{R}=0.976)$. Among macrofauna, molluscs constituted the most abundant group inshore, whereas annelids were more abundant offshore. The characteristics of the offshore sediments with high TOC contents could have limited the abundance of suspension feeders such as bivalves, favouring at the same time infaunal benthos such as annelids (Semprucci et al., 2010).

Bivalves were mainly represented by Corbula gibba, while amphipods by Ampelisca spinipes and both species were typical of the inshore stations. The bivalve $C$. gibba is considered as an indicator of environmental instability, low oxygen content and organic enrichment. This species tends, in fact, to form dense populations where the macrofaunal community is characterised by low diversity as in constantly or occasionally unbalanced environments (HrsBrenko, 2006). In contrast, the fossorial crustacean Ampelisca acts as a bioturbator, which builds and irrigates its burrows and, in conditions of $\mathrm{O}_{2}$ depletion, creates a small oxidized cylinder within the sediment enhancing sea bottom oxygenation. Therefore Ampelisca is considered a structural taxon since, modifying the substratum, makes it more suitable for supporting other species. For this reason, Ampelisca has been credited as a good bioindicator of environmental recovery. In recent years, a sensible reduction of $C$. gibba average number has been reported along the Emilia Romagna coastline, compared to the period of 1980- 2000 (N'Siala et al., 2008). Furthermore, the increased abundances of Ampelisca suggest a gradual amelioration of the environmental status of the Italian coasts.
The PCA confirmed the presence of two distinct environmental contexts within which different benthic communities develop. The stations with depths $<20 \mathrm{~m}$ have a higher percentage of sand and seem to be influenced by nutrient loads of terrestrial origin as confirmed by higher DIN and Chl $a$ values (in September). The latter, in fact, can generally provide a good indication of labile organic inputs to sediments (Boon and Duineveld, 1998). These environmental conditions likely influence the three benthic communities analysed, resulting in assemblages dominated by tolerant and opportunistic taxa (Gyrosigma and C. gibba) and groups of organisms (nematodes). The stations with depths $>20 \mathrm{~m}$ have muddier sediments that likely restrain more TOC than inshore ones. These environmental features could enhance deposit feeders, such as macrofaunal annelids, for whom the accumulation of TOC could represent a noteworthy food source.

\section{CONCLUSIONS}

In the study area, the three benthic communities showed a clear depth-related distribution. The isobath of $20 \mathrm{~m}$ seems to influence the selection of distinct inshore $v s$ offshore autotrophic and heterotrophic benthic communities. Besides this purely physical feature, also the chemistry of sediments likely affects the studied communities. In fact, the gradual increase of the distance from the coastline likely determines a dilution effect of the inorganic loads from the land as indicated by the decreasing concentrations of DIN. However, with the exception of the dissolved inorganic forms of nitrogen, that could be considered a proxy of terrestrial organic inputs, our data did not highlight the presence of a clear anthropogenic impact on the investigated benthic communities. The co-occurrence of sensitive taxa such as meiofaunal copepods and Ampelisca with opportunistic ones (as C. gibba) suggests that the benthic domain is only moderately impacted.

It was beyond the aim of this study to estimate the benthic diatom community production. However, the presence of a viable benthic diatom community at depths of about $50 \mathrm{~m}$ extends the known depth range of these primary producers and holds significant implications for oceanic primary production and biogeochemical cycling. Interestingly, sciaphilous conditions even at depths $\sim 50 \mathrm{~m}$ enhanced the presence of diatoms able to switch from the autotrophic to heterotrophic metabolism as Paralia sulcata.

\section{ACKNOWLEDGEMENTS}

The authors would like to thank C. Comici for TN and TOC data, C. Falconi and M. Kralj for nutrient analysis, M. Lipizer for pigment analysis, M. Bussi for granulometric determination and D. Borme for his help during sampling. 
The authors warmly thank the crew of the R/V-Daphne and the Environmental Protection Agency of Emilia-Romagna region for the logistical support. A special thanks goes to R. Auriemma for his help with the statistical analysis.

\section{REFERENCES}

Albertelli G, Covazzi-Harriague A, Danovaro R, Fabiano M, Fraschetti S, Pusceddu A, 1999. Differential responses of bacteria, meiofauna and macrofauna in a shelf area (Ligurian Sea, NW Mediterranean): role of food availability. J. Sea Res. 42:11-26.

Balsamo M, Albertelli G, Ceccherelli VU, Coccioni R, Colangelo MA, Curini-Galletti M, Danovaro R, D'Addabbo R, De Leonardis C, Fabiano M, Frontalini F, Gallo M, Gambi C, Guidi L, Moreno M, Pusceddu A, Sandulli R, Semprucci F, Todaro MA, Tongiorgi P, 2010. Meiofauna of the Adriatic Sea: present knowledge and future perspectives. Chem. Ecol. 26:45-63.

Barranguet C, 1997. The role of microphytobenthic primary production in a Mediterranean mussel culture area. Estuar. Coast. Shelf S. 44:753-765.

Bonaglia S, Nascimento FJA, Bartoli M, Klawonn I, Brüchert $\mathrm{V}, 2014$. Meiofauna increases bacterial denitrification in marine sediments. Nat. Commun. 5:5133.

Boon AR, Duineveld GCA, 1998. Chlorophyll a as a marker for bioturbation and carbon flux in southern and central North Sea sediments. Mar. Ecol.-Prog. Ser. 162:33-43.

Cahoon LB, 1999. The role of benthic microalgae in neritic ecosystems. Oceanogr. Mar. Biol. Annu. Rev. 37:47-86.

Castelli A, Lardicci C, Tagliapietra D, 2004. Soft bottom macrobenthos. In: M.C. Gambi, and M. Dappiano (eds.), Mediterranean marine benthos: a manual of methods for its sampling and study. Biol. Mar. Medit. 11(Suppl. 1):99-131.

Cibic T, Blasutto O, Falconi C, Fonda Umani S, 2007. Microphytobenthic biomass, species composition and nutrient availability in sublittoral sediments of the Gulf of Trieste (northern Adriatic Sea). Estuar. Coast. Shelf S. 75:50-62.

Cibic T, Comici C, Bussani A, Del Negro P, 2012. Benthic diatom response to changing environmental conditions. Estuar. Coast. Shelf S. 115:158-169.

Cibic T, Facca C, 2010. Microphytobenthos. In: G. Relini (ed.), Checklist della flora e della fauna dei mari italiani. Parte II. Biol. Mar. Medit 17(Suppl.1):754-800.

Clarke A, Gorely RN, 2006. PRIMER v6: user maual/tutorial. PRIMER-E Ltd, Plymouth, UK.

Clarke KR, Warwick RM, 2001. Change in marine communities: an approach to statistical analysis and interpretation. PRIMER-E LDT, Plymouth, UK.

Colantoni P, Fanzutti GP, Marocco R, 1985. Geologia della piattaforma adriatica. Progetto Finalizzato Oceanografia e Fondi Marini, Sottoprogetto Risorse Minerarie, Rapporto tecnico finale, pp. 59-85.

Cozzi S, Giani M, 2011. River water and nutrient discharges in the Northern Adriatic Sea: Current importance and long term changes. Cont. Shelf Res. 31:1881-1893.

Creel L, 2003. Ripple effects: population and coastal regions. Population Reference Bureau, Washington, DC, USA.

Crema R, Castelli A, Prevedelli D, 1991. Long term eutrophi- cation effects on macrofaunal communities in northern Adriatic Sea. Mar. Pollut. Bull. 22:503-508.

Crise A, Kaberi H, Ruiz J, Zatsepin A, Arashkevich E, Giani M, Karageorgis AP, Prieto L, Pantazi M, Gonzalez-Fernandez D, Ribera d'Alcalà M, Tornero V, Vassilopoulou V, Durrieu de Madron X, Guieu C, Puig P, Zenetos A, Andral B, Angel D, Altukhov D, Ayata SD, Aktan Y, Balcığlu E, Benedetti F, Bouchoucha M, Buia MC, Cadiou JF, Canals M, Chakroun M, Christou E, Christidis MG, Civitarese G, Coatu V, CorsiniFoka M, Cozzi S, Deidun A, Dell'Aquila A, Dogrammatzi A, Dumitrache C, Edelist D, Ettahiri O, Fonda-Umani S, Gana S, Galgani F, Gasparini S, Giannakourou A, Gomoiu MT, Gubanova A, Gücü AC, Gürses Ö, Hanke G, Hatzianestis I, Herut B, Hone R, Huertas E, Irisson JO, İşinibilir M, Jimenez JA, Kalogirou S, Kapiris K, Karamfilov V, Kavadas S, Keskin Ç, Kideyş AE, Kocak M, Kondylatos G, Kontogiannis C, Kosyan R, Koubbi P, Kušpilić G, La Ferla R, Langone L, Laroche S, Lazar L, Lefkaditou E, Lemeshko IE, Machias A, Malej A, Mazzocchi MG, Medinets V, Mihalopoulos N, Miserocchi S, Moncheva S, Mukhanov V, Oaie G, Oros A, Öztürk AA, Öztürk B, Panayotova M, Prospathopoulos A, Radu G, Raykov V, Reglero P, Reygondeau G, Rougeron N, Salihoglu B, Sanchez-Vidal A, Sannino G, Santinelli C, Secrieru D, Shapiro G, Simboura N, Shiganova T, Sprovieri M, Stefanova K, Streftaris N, Tirelli V, Tom M, Topaloğlu B, Topçu NE, Tsagarakis K, Tsangaris C, Tserpes G, Tuğrul S, Uysal Z, Vasile D, Violaki K, Xu J, Yüksek A, Papathanassiou E, 2015. A MSFD complementary appraoch for the assessment of pressures, knowledge and data gaps in Southern European Seas: The PERSEUS experience. Mar. Pollut. Bull. 95:28-39.

Danovaro R, Fraschetti S, Belgrano A, Curini-Galletti M, Vincx M, Alberelli G, Fabiano M, 1995. The potential impact of meiofauna on the recruitment of macrobenthos in a subtidal coastal benthic community of the Ligurian Sea: a field result, p. 115-122. In: A. Eleftheriou, A.D. Ansell and C.J. Smith (eds.), Biology and ecology of shallow coastal waters. Olsen \& Olsen, Fredenborg.

Danovaro R, Gambi MC, Manini E, Fabiano M, 2000. Meiofauna response to a dynamic river plume front. Mar. Biol. 137:359-370.

Danovaro R, Gambi C, Mirto S, Sandulli R, Ceccherelli VU, 2004. Meiofauna. In: M.C. Gambi and M. Dappiano (eds.), Mediterranean marine benthos: a manual of methods for its sampling and study. Biol. Mar. Medit. Vol 11(Suppl 1):55-97.

Dexing J, Junmin L, Zhaodi C, Shicheng L, 1985. Marine Benthic Diatoms in China. China Ocean Press, Beijing: 313 pp.

European Commission, 2008. Directive 2008/56/EC of the European Parliament and of the Council establishing a framework for community action in the field of marine environmental policy (Marine Strategy Framework Directive). Official Journal, L164, pp. 19-40.

Fain AMV, Ogston AS, Sternberg RW, 2007. Sediment transport event analysis on the western Adriatic continental shelf. Cont. Shelf Res. 27:431-451.

Frontalini F, Semprucci F, Coccioni R, Balsamo M, Bittoni P, Covazzi-Harriague A, 2011. On the quantitative distribution and community structure of meio and macrofaunal communities in the coastal area of the Central Adriatic Sea (Italy). Environ. Monit. Assess. 180:325-344.

Germain H, 1981. Flore des diatomées eaux douces et 
saumâtres.[Book in French]. Société Nouvelle des Éditions Boubée, Paris: 444 pp.

Grasshoff K, Ehrhardt M, Kremling K, Almgren T, 1983. Methods of seawater analysis. Verlag Chemie, Weinheim: $419 \mathrm{pp}$.

Hendey NI, 1976. An introductory account of the smaller algae of British coastal waters. Otto Koeltz Science Publishers, Koenigstein: 317 pp.

Higgins RP, Thiel H, 1988. Introduction to the study of meiofauna. Smithsonian Institution Press, Washington DC: 488 pp.

Hrs-Brenko M, 2006. The basket shell Corbula gibba as a species resistant to environmental disturbaces. Acta Adriat. 47:49-64.

Hunter J, 2007. Diatoms as environmental indicators: a case study in the bioluminescent bays of Vieques, Puerto Rico. Proceedings of the $20^{\text {th }}$ Annual Keck Symp. Wooster, OH, USA. Available from: http://keckgeology.org/files/pdf/ symvol/20th/puertorico/hunter.pdf

Larson F, Sundbäck K, 2008. Role of microphytobenthos in recovery of functions in a shallow-water sediment system after hypoxic events. Mar. Ecol.-Prog. Ser. 357:1-16.

Lorenzen C, Jeffrey J, 1980. Determination of chlorophyll in sea water. UNESCO Technical Paper in Marine Science 35. Avallabile from: http://unesdoc.unesco.org/images/0004/ 000434/043485EB.pdf

Manoukian S, Spagnolo A, Scarcella G, Punzo E, Angelici R, Fabi G, 2010. Effects of two offshore gas platforms on softbottom benthic communities (northwestern Adriatic Sea, Italy). Mar. Environ. Res. 70:402-410.

Margalef R, 1986. Ecologia. Omega, Barcellona: 951 pp.

MacIntyre HL, Richard JG, Miller DG, 1996. Microphytobenthos: the ecological role of the "secret garden" of unvegetated, shallow-water marine habitats. I. Distribution, abundance and primary production. Estuaries19:186-201.

Massamba N'Siala G, Grandi V, Iotti M, Montanari G, Prevedelli D, Simonini R, 2008. Responses of a Northern Adriatic Ampelisca-Corbula community to seasonality and short-term changes in the Po river. Mar. Environ. Res. 66:466-476.

McGee D, Laws RA, Cahoon LB, 2008. Live benthic diatoms from the upper continental slope: extending the limits of marine primary production. Mar. Ecol.-Prog. Ser. 356:103-112.

McQuoid MR, Nordberg K, 2003. The diatom Paralia sulcata as an environmental indicator species in coastal sediments. Estuar. Coast. Shelf S. 56:339-354.

Morri C, Bellan-Santini D, Giaccone G, Bianchi CN, 2004. Principles of bionomy: definition of assemblages and use of taxonomic descriptors (Macrobenthos. In: M.C. Gambi and M. Dappiano (eds), Mediterranean marine benthos: a manual of methods for its sampling and study. Biol.a Mar. Medit. 11(Suppl.1):573-600.

Mozetič P, Solidoro C, Cossarini G, Socal G, Precali R, Francé J, Bianchi F, De Vittor C, Smodlaka N, Fonda Umani S, 2010.Recent trends towards oligotrophication of the northern Adriatic: evidence from Chlorophyll a time series. Estuar. Coasts 33:362-375.

Nieuwenhuize J, Maas YEM, Middelburg JJ, 1994. Rapid analysis of organic carbon and nitrogen in particulate materials. Mar. Chem. 45:217-224.

Pella E, Colombo B, 1973. Study of carbon, hydrogen and nitrogen determination by combustion-gas chromatography. Mikrochim. Acta 5:697-719.

Poulain P-M, Kourafalou VH, Cushman-Roisin B, 2001. Northern
Adriatic Sea, p. 143-165. In: B. Cushman-Roisin, M. Gačić, P-M. Poulain and A. Artegiani (eds)., Physical oceanography of the Adriatic Sea. Kluwer Academic Publisher.

Ravaioli M, Alvisi F, Menegazzo-Vitturi L, 2003. Dolomite as a tracer for sediment transport and deposition on the northwestern Adriatic continental shelf (Adriatic Sea, Italy). Cont. Shelf Res. 23:1359-1377.

Ricard M, 1987. Atlas du phytoplancton marin. 2. Diatomophycées. [Book in French]. Centre National de la Recherché Scientifique, Paris: 297 pp.

Round FE, Crawford RM, Mann DG, 1992. The diatoms. Cambridge University Press, Avon: 747 pp.

Schlitzer R, 2015. Ocean Data View. Available from: http://odv. awi.de

Semprucci F, Boi P, Manti A, Covazzi-Harriague A, Rocchi M, Colantoni P, Papa S, Balsamo M, 2010. Benthic communities along a littoral of the Central Adriatic Sea (Italy). Helgol. Mar. Res. 64:101-115.

Semprucci F, Frontalini F, Covazzi-Harriague A, Coccioni R, Balsamo M, 2013. Meio- and macrofauna in the marine area of the Monte St. Bartolo Natural Park (Central Adriatic Sea, Italy). Sci. Mar. 77:189-199.

Semprucci F, Losi V, Moreno M, 2015. A review on Italian research on free-living marine nematodes and the future perspectives on their use as Ecological Indicators (EcoInds). Medit. Mar. Sci. 16:352-365.

Shannon CE, Weaver W, 1949. The mathematical theory of communication. Illinois Press, Urbana: 117 pp.

Sharp JH, 1974. Improved analysis for "particulate" organic carbon and nitrogen from seawater. Limnol. Oceanogr. 19:984-989.

Shepard FP, 1954. Nomenclature based on sand silt clay ratios. J. Sediment. Petrol. 24:151-158.

Simonini R, Ansaloni I, Bovini P, Grandi V, Graziosi F, Iotti M, Massamba N'Siala G, Mauri M, Montanari G, Preti M, De Nigris N, Prevedelli D, 2007. Recolonization and recovery dynamics of the macrozoobenthos after sand extraction in relict sand bottoms of the Northern Adriatic Sea. Mar. Environ. Res. 64:574-589.

Simonini R, Ansaloni I, Bonvicini Pagliai AM, Cavallini F, Iotti M, Mauri M, Montanari G, Preti M, Rinaldi A, Prevedelli D, 2005a. The effects of sand extraction on the macrobenthos of a relict sands area (Northern Adriatic Sea): results 12 months post-extraction. Mar. Pollut. Bull. 50:68-777.

Simonini R, Ansaloni I, Cavallini F, Graziosi F, Iotti M, Massamba N'Siala G, Mauri M, Montanari G, Preti M, Prevedelli D, 2005b. Effects of long-term dumping of harbor-dredged material on macrozoobenthos at four disposal sites along the Emilia-Romagna coast (Northern Adriatic Sea, Italy). Mar. Pollut. Bull. 50:1595-1605.

Simpson EH, 1949. Measurement of diversity. Nature 163:688.

Sundbäck K, Linares F, Larson F, Wulff A, 2004. Benthic nitrogen fluxes along a depth gradient in a microtidal fjord: the role of denitrification and microphytobenthos. Limnol. Oceanogr. 49:1095-1107.

Tomadin L, 2000. Sedimentary fluxes and different dispersion mechanisms of the clay sediments in the Adriatic Basin. Rend. Fis. Accad. Lincei 11:161-174.

Tomas CR, 1997. Identifying marine phytoplankton. Academic Press, San Diego: 858 pp.

Totti C, 2003. Influence of the plume of the river Po on the dis- 
tribution of subtidal microphytobenthos in the Northern Adriatic Sea. Bot. Mar. 46:161-178.

Traykovski P, Wiberg PL, Geyer WR, 2007. Observations and modelling wave-supported sediment gravity flows on the Po prodelta and comparison to prior observations from the Eel shelf. Continent. Shelf Res. 27:357-399.

Tuchmann NC, Schollett MA, Rier ST, Geddes P, 2006. Differential heterotrophic utilization of organic compounds by diatoms and bacteria under light and dark conditions. Hydrobiologia 561:167-177.

Utermöhl H, 1958. Zur Vervollkommnung der quantitativen Phytoplankton-Methodik.[Article in German]. Mitt. Int. Ver. Theor. Angew. Limnol. 9:1-38.
Van Heurck H, 1899. Traité des diatomées. Édité aux frais de l'auteur, Anvers: 572 pp.

Witkowski A, Lange-Bertalot A, Metzeltin D, 2000. Iconographia diatomologica. 7. Annotated diatom micrographs. ARG Gantner Verlag KG: 925 pp.

Zonneveld KAF, Versteegh GJM, Kasten S, Eglinton TI, Emeis K-C, Huguet C, Koch BP, de Lange GJ, de Leeuw JW, Middelburg JJ, Mollenhauer G, Prahl FG, Rethemeyer J, Wakeham SG, 2010. Selective preservation of organic matter in marine sediments; processes and impact on sedimentary record. Biogeosciences 7:483-511. 